Ecosystem Management and Restoration Research Program

\title{
Floristic Quality Index of Restored Wetlands in Coastal Louisiana
}

Glenn M. Suir and Charles E. Sasser

August 2017

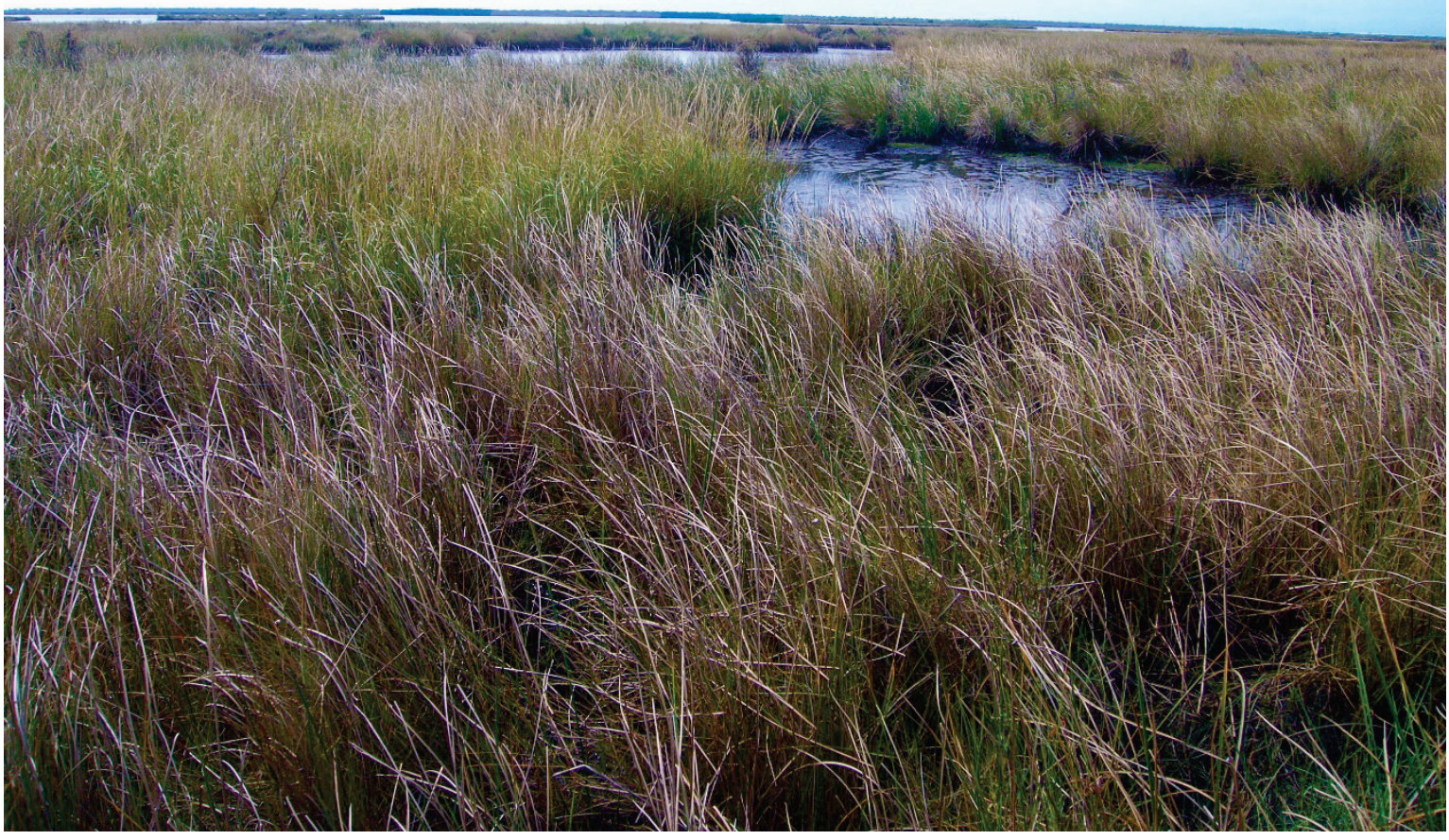


The U.S. Army Engineer Research and Development Center (ERDC) solves the nation's toughest engineering and environmental challenges. ERDC develops innovative solutions in civil and military engineering, geospatial sciences, water resources, and environmental sciences for the Army, the Department of Defense, civilian agencies, and our nation's public good. Find out more at www.erdc.usace.army.mil.

To search for other technical reports published by ERDC, visit the ERDC online library at http://acwc.sdp.sirsi.net/client/default. 


\title{
Floristic Quality Index of Restored Wetlands in Coastal Louisiana
}

\author{
Glenn M. Suir \\ Environmental Laboratory \\ U.S. Army Engineer Research and Development Center \\ Wetlands and Environmental Technologies Research Facility \\ Louisiana State University - Military Sciences Building \\ Baton Rouge, LA 70803 \\ Charles E. Sasser \\ Louisiana State University \\ School of the Coast and Environment \\ Department of Oceanography and Coastal Sciences \\ Energy Coast and Environment Building \\ Baton Rouge, LA 70803
}

Final report

Approved for public release; distribution is unlimited.

Prepared for U.S. Army Corps of Engineers

Washington, DC 20314-1000

Under Project 454745, Use of Remote Sensing Technologies and Field Data Collection to Quantify the Effects of Dedicated Dredging and Use of Dredged Sediments for Ecosystem Restoration. 


\section{Abstract}

Restoration efforts in the United States have created or benefitted large expanses of wetlands. Typical goals of wetland restoration efforts are to conserve, create, or enhance wetland form and to achieve wetland function that approaches natural conditions. Measures of wetland condition have been used to monitor and assess project performance, resilience, and adaptive management needs. An emerging tool for performing bioassessments in wetland systems is the Floristic Quality Index (FQI). This study assessed the use of a modified FQI (FQI mod) to evaluate site development, plant community establishment, and wetland condition. Three restoration sites in coastal Louisiana were used to evaluate the

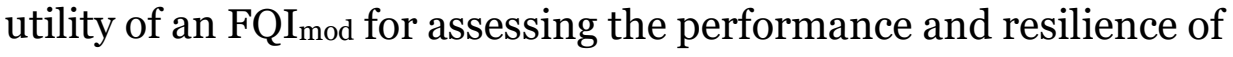
restored wetlands by comparison to reference wetlands. Results demonstrate that the FQI mod data successfully reflected large disturbance events - namely hurricanes and salinity spikes. The data also identified vegetation differences due to elevation, age, and hydrology. The modified FQI provided useful measures of restoration type (e.g., planted versus not planted, marsh creation versus nourishment), chronosequence (condition and stability over time), and trajectory (i.e., intersecting trend lines when restored marsh FQI approaches reference marsh condition). The FQImod provides a rapid and effective system for assessing wetland condition and performance.

DISCLAIMER: The contents of this report are not to be used for advertising, publication, or promotional purposes. Citation of trade names does not constitute an official endorsement or approval of the use of such commercial products. All product names and trademarks cited are the property of their respective owners. The findings of this report are not to be construed as an official Department of the Army position unless so designated by other authorized documents. 


\section{Contents}

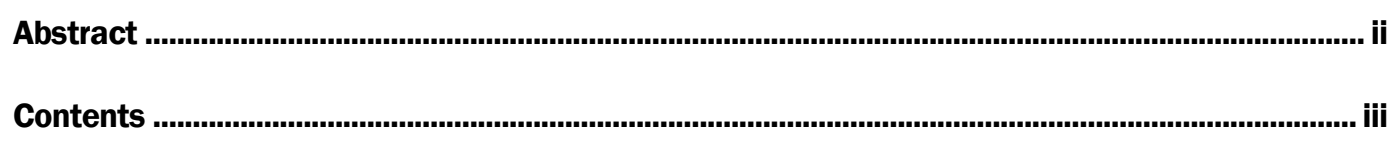

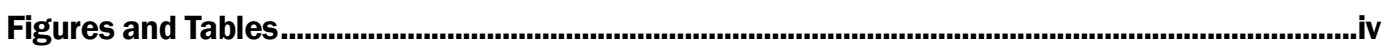

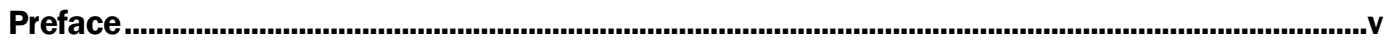

Unit Conversion Factors ..................................................................................................................

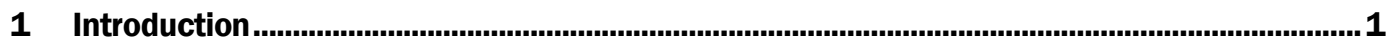

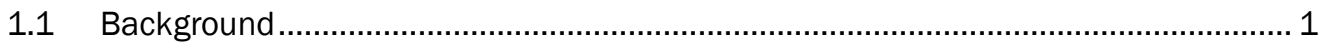

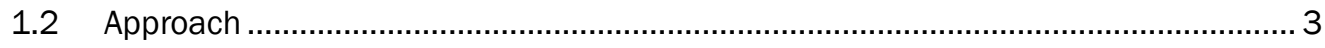

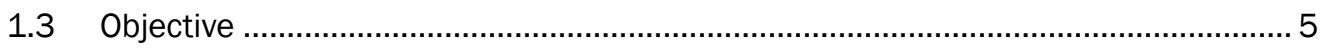

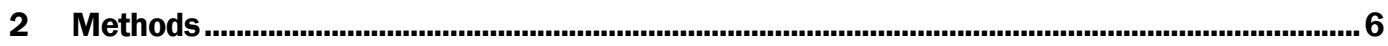

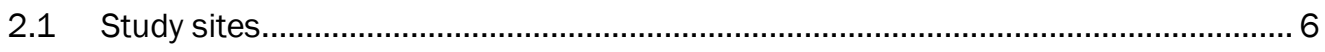

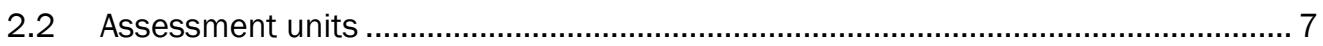

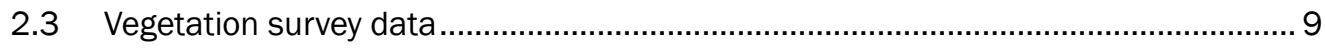

2.4 Floristic quality index .................................................................................... 9

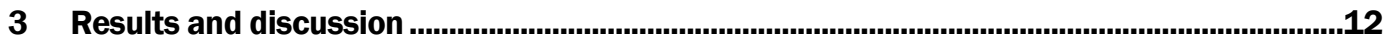

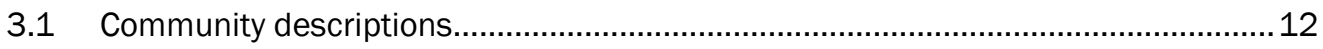

3.1.1 Sabine vegetation ........................................................................................ 12

3.1.2 Atchafalaya vegetation ............................................................................. 14

3.1.3 Little Lake vegetation .................................................................................. 16

3.2 Coefficients of conservatism ....................................................................... 21

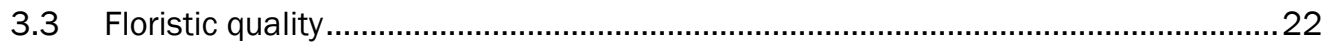

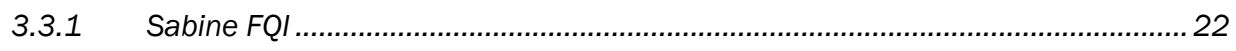

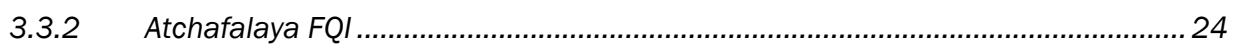

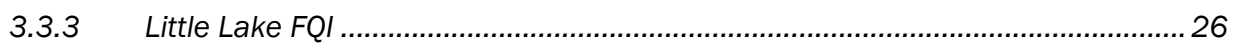

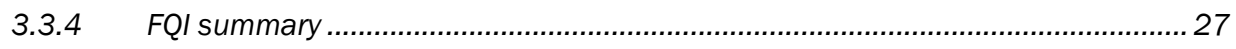

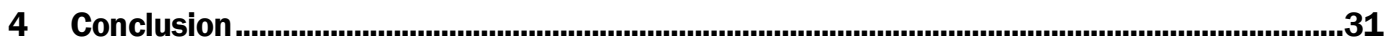

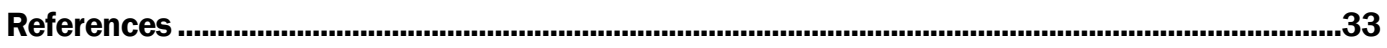

\section{Report Documentation Page}




\section{Figures and Tables}

\section{Figures}

Figure 1. Location map of study areas (Sabine, Little Lake, and Atchafalaya), assessment units (Project, Project Reference, and Subwatershed Reference), and data collection sites. 8

Figure 2. Percent cover and $\mathrm{CC}$ values for species within the Sabine assessment units

Figure 3. Percent cover and $\mathrm{CC}$ values for species within the Atchafalaya assessment units.

Figure 4. Percent cover and CC values for species within the Little Lake assessment units............20

Figure 5. Average $\mathrm{CC}$ for all survey stations within study site assessment units.

Figure 6. Floristic Quality Index ( $\left.F Q I_{m o d}\right)$ scores for all survey stations within the Sabine assessment units by year. Vertical lines and inset chart provide tropical storm (TS) activity (wind speed miles per hour) and salinity data, respectively.

Figure 7. Floristic Quality Index ( $\mathrm{FQI}_{\mathrm{mod}}$ ) scores for all survey stations within the Atchafalaya assessment units by year. Vertical lines and inset chart provide tropical storm (TS) activity (wind speed miles per hour) and salinity data, respectively.

Figure 8. Floristic Quality Index (FQI ${ }_{\text {mod }}$ ) scores for all survey stations within the Little Lake assessment units by year. Vertical lines and inset chart provide tropical storm (TS) activity (wind speed miles per hour) and salinity data, respectively.

\section{Tables}

Table 1. General description and criteria for assignment of Coefficient of Conservatism (CC) scores to different plant species (based on Andreas et al. 2004, Cohen et al. 2004, Cretini et al. 2012, and Swink and Wilhelm 1994).

Table 2. Number of vegetation survey stations within each study site and assessment unit.

Table 3. Preliminary ideal range for vegetation indices in Louisiana's principal geological settings. (Cretini et al. 2011)

Table 4. Mean FQImod by year for each assessment unit within the Sabine study sites. Differences in FQI between Project (P) and Subwatershed Reference (SR) and Project Reference (PR) are provided and color coded (dark green represents difference values near 100 and dark red represents values near -100).

Table 5. Mean FQImod by year for each assessment unit within the Atchafalaya study sites. Differences in FQI between Project (P) and Subwatershed Reference (SR) and Project Reference (PR) are provided and color coded (dark green represents difference values near 100 and dark red represents values near -100).

Table 6. Mean FQImod by year for each assessment unit within the Little Lake study sites. Differences in FQI between Project (P) and Subwatershed Reference (SR) and Project Reference (PR) are provided and color coded (dark green represents difference values near 100 and dark red represents values near -100 ). 


\section{Preface}

The work reported herein was conducted as part of the Ecosystem Management and Restoration Research Program (EMRRP). The EMRRP is sponsored by Headquarters, U.S. Army Corps of Engineers (HQUSACE), and is assigned to the U.S. Army Engineer Research and Development Center (ERDC) under the purview of the Environmental Laboratory (EL), Vicksburg, Mississippi. The EMRRP is managed under the Civil Works Environmental Engineering and Sciences Office, Dr. Alfred F. Cofrancesco, Technical Director. Dr. Trudy Estes was Program Manager of the EMRRP. The program monitor during this study was Mr. Timothy R. Toplisek, HQUSACE; the USACE Proponent for EMRRP is Ms. Mindy Simmons.

Support and cooperation for this work were provided by the U.S. Army Corps of Engineers, New Orleans District; the U.S. Fish and Wildlife Services; the Louisiana Department of Wildlife and Fisheries; and the Little Lake Land Corporation.

The authors would like to thank Mr. Sam Jackson and Ms. Christina Saltus for review of the technical report and Mr. Lance Campbell, Mr. Robert Dubois, and Mr. Randal Moertle for technical assistance with this project.

This work was performed under the general supervision of Mr. Mark Graves, Chief, EEC; Mr. Mark Farr, Chief, EE; and Dr. Beth Fleming, Director, EL. At the time of publication of this report, Dr. David W. Pittman was Director of ERDC; COL Bryan S. Green was Commander of ERDC. 


\section{Unit Conversion Factors}

\begin{tabular}{|l|c|l|}
\hline Multiply & By & To Obtain \\
\hline acres & $4,046.873$ & square meters \\
\hline cubic yards & 0.7645549 & cubic meters \\
\hline feet & 0.3048 & meters \\
\hline miles (U.S. statute) & $1,609.347$ & meters \\
\hline miles per hour & 0.44704 & meters per second \\
\hline
\end{tabular}




\section{Introduction}

\subsection{Background}

Wetlands in the United States were once viewed as nuisance wastelands that bred disease, restricted overland travel, and hindered development; consequently, many were drained and farmed or developed by the first European settlers (Dahl and Allord 1996). Due primarily to these conversions, the amount of wetlands in the conterminous United States was reduced from approximately 221 million acres in the early 1660 s, to an estimated 110 million acres by the year 2010 (Dahl and Allord 1996, Dahl 2010). Some wetlands, like those in coastal Louisiana, have experienced significant loss not only due to human activity but also to natural processes. The 1.2 million acres of wetlands lost in coastal Louisiana from 1932 to 2010 (a net wetland change of -25\%) can be attributed to an assemblage of factors. The primary factors consist of subsidence, sea-level rise, hurricanes, floods, oil and gas exploration and extraction, salt water intrusion due to channelization, and sediment and nutrient deprivation due to flood protection measures (Couvillion et al. 2011).

In the last half century, research has shown that these "wastelands" are actually among the most productive and beneficial ecosystems in the world. Wetlands provide benefits that range from regulating services (floods, drought, and land degradation); supporting services (soil formation and nutrient cycling); provisioning services (food and freshwater); and cultural services (recreational and aesthetic); to maintaining high biological productivity and serving as critical habitat for fish and wildlife (Millennium Ecosystem Assessment 2003, USACE 2013). With an increasing understanding of wetland importance, federal and state governments enacted a number of policies, regulations, and incentive programs to directly and indirectly protect, maintain, and restore the wetlands of the United States (Votteler and Muir 1996). Many federal and state agencies and local stakeholders share responsibilities for maintaining or restoring the Nation's wetlands.

In the United States, restoration efforts began small but soon developed into larger authorities and programs such as the Coastwide Wetland Planning and Protection Restoration Act (CWPPRA); the USACE Beneficial Use of Dredged Material (BUDM) programs; and state-led 
master plans. In Louisiana, CWPPRA and BUDM programs have created or benefitted nearly 100,000 acres of wetlands collectively (Louisiana Coastal Wetlands Conservation and Restoration Task Force (LCWCRTF) 2015a). Additionally, the Louisiana Coastal Master Plan conservatively estimates (depending on future coastal conditions) that over 371,000 acres of land will be created or nourished using numerous restoration measures (Coastal Protection and Restoration Authority of Louisiana 2012).

Typical goals of wetland restoration efforts are to conserve, create, or enhance wetland form and to achieve wetland function that approaches natural conditions. Though wetland form and function are driven by many factors, the dominant factors include elevation, hydrology, sedimentation, and vegetation (USGS 1997). For a constructed wetland, failure to adequately manage one of these elements can negatively impact others, ultimately degrading wetland condition (Cohen et al. 2004).

Measures of wetland condition have been used to monitor and assess project performance, resilience, and adaptive management needs. There are three basic levels of wetland monitoring and assessment: 1) landscape assessment - which consists of coarse inventory information that is acquired and assessed using remote sensing and geographic information system (GIS) techniques; 2) rapid assessments - which are site-specific analyses using regionally derived and relatively simple and rapid protocols (e.g., Louisiana Wetland Rapid Assessment Method (LRAM)); and 3) intensive site assessments - consisting of research-derived, multi-metric indices that give detailed information about wetland function (e.g., the Hydrogeomorphic (HGM) Approach) (U.S. Environmental Protection Agency (USEPA) 2002b). Regardless of level, each assessment type provides metrics and indices that translate into descriptions of biological condition (Karr and Chu 1997). Landscape assessments are useful information when evaluating wetland change trajectories or analyzing direct episodic impacts across larger spatial and temporal scales. However, they may not be suitable for analyzing complex and dynamic systems. Conversely, intensive site assessments provide detailed information that are necessary for analyzing complex systems, but these assessments are customarily labor and resource intensive; unless high levels of detail are required, they can be unnecessary and impractical.

Rapid assessments are useful when general site-specific wetland ecological conditions are required. Evaluations of wetland ecological condition 
require biological indices that measure or estimate wetland quantity and quality. Plants are excellent indicators of wetland function and condition because of their high levels of species richness, rapid growth rates, and direct response to environmental stressors and disturbances (Cohen et al. 2004, Mack 2007, Smith et al. 1995, USEPA 2002a). Specifically, plant species composition, cover, density, and biomass are structural components of coastal marshes that are commonly used to quantify vegetative characteristics and often serve as indicators of wetland condition (Chamberlain and Ingram 2012, Cretini et al. 2012). Though these structural components are useful for quantifying wetland characteristics, they are deficient at evaluating wetland quality. Wetland plant quality is an essential metric because it provides critical information related to habitats, effectiveness of restoration measures, resilience to disturbance events, and adaptive management needs and priorities (USEPA 2002a).

\subsection{Approach}

An emerging tool for performing bioassessments in wetland systems is the Floristic Quality Index (FQI). The FQI, a USEPA endorsed tool, has been used to identify areas of high conservation value, monitor critical landscapes, assess impacts from disturbance events, measure wetland ecological condition, assist in habitat restoration and mitigation policy, and compare restoration sites to reference sites (Bourdaghs et al. 2006, Fennessy et al. 2002, Gianopulos 2014). Where most other quality assessments are highly subjective, the FQI provides a rapid assessment that is a standardized, repeatable technique capable of comparing different vegetation and community types (Nichols 1999, Stapanian 2016). FQI provides an estimate of habitat quality based on a measure of vulnerability, called the Coefficient of Conservatism (CC), together with the richness or cover of a plant community (Gianopulos 2014). CC values range from zero (not conservative) to ten (conservative and highly ecologically sensitive), and are assigned to individual plant species within a local flora by a panel of experienced botanists, primarily based on their best professional judgment (Bourdaghs et al. 2006, Little 2013). Since the impact and function of plant species differ by region, $\mathrm{CC}$ values are specific to state or region (Little 2013). Table 1 provides the criteria that is typically used to assign CC values to individual plant species. Species are also assigned to general classes based on species characteristics. These classes include invasive plant species ( $\mathrm{CC}$ value of $\mathrm{o})$, disturbance species $(\mathrm{CC}=$ $1-3$ ), vigorous wetland communities $(\mathrm{CC}=4-6)$, common species $(\mathrm{CC}=$ $7-8)$, and dominant wetland species $(\mathrm{CC}=9-10)$. 
Table 1. General description and criteria for assignment of Coefficient of Conservatism (CC) scores to different plant species (based on Andreas et al. 2004, Cohen et al. 2004, Cretini et al. 2012, and Swink and Wilhelm 1994).

\begin{tabular}{|l|l|l|}
\hline General characteristics of species & Criteria & cc \\
\hline Invasive plant species & Obligate to ruderal areas & 0 \\
\hline \multirow{2}{*}{$\begin{array}{l}\text { Plants that are opportunistic users of } \\
\text { disturbed sites }\end{array}$} & Occurs more frequently in ruderal areas than natural areas & 1 \\
\cline { 2 - 3 } & Facultative to ruderal and natural areas & 2 \\
\cline { 2 - 3 } & Occurs less frequent in ruderal areas than natural areas & 3 \\
\hline \multirow{2}{*}{$\begin{array}{l}\text { Plants that occur primarily in less } \\
\text { communities }\end{array}$} & $\begin{array}{l}\text { Occurs much more frequently in natural areas than ruderal } \\
\text { areas }\end{array}$ & 4 \\
\cline { 2 - 3 } & Obligate to natural areas (quality of area is low) & 5 \\
\cline { 2 - 3 } & Weak affinity to high-quality natural areas & 6 \\
\hline \multirow{2}{*}{$\begin{array}{l}\text { Plants that are common in vigorous } \\
\text { coastal wetland communities }\end{array}$} & Moderate affinity to high-quality natural areas & 7 \\
\cline { 2 - 3 } & High affinity to high-quality natural areas & 9 \\
\hline \multirow{2}{*}{$\begin{array}{l}\text { Plants that are dominants in vigorous } \\
\text { coastal wetland communities }\end{array}$} & Very high affinity to high-quality natural areas & 10 \\
\cline { 2 - 3 } & Obligate to high-quality natural areas & 8 \\
\hline
\end{tabular}

Various iterations of the Floristic Quality Index have been used to assess vegetation conditions across a wide range of geomorphic settings and ecosystems. The initial Floristic Quality Assessment Index (FQAI), developed by Swink and Wilhelm (1979), is a weighted metric that was developed to assess the quality of native plant communities (invasive species were not included in early FQI assessments). All native species within a sample site are used to calculate the FQAI as follows:

$$
\mathrm{FQAI}=\sum_{i}^{S} C C_{i} / \sqrt{N}_{\text {native }}
$$

where $\mathrm{CC}_{i}$ is the coefficient of conservatism of species $i$, and $\mathrm{N}_{\text {native }}$ is the total number of native species found at the site (Andreas et al. 2004).

Appraisals of the FQI process have focused on the nature in which CC values are assigned to plant species. Numerous studies have been conducted to compare expert-panel-derived CC values and empirically derived values to assess the subjectivity and accuracy of the values (Bourdaghs et al. 2006, Cohen et al. 2004, Chamberlain and Ingram 2012, Mortellaro et al. 2012, Mushet et al. 2002, Rocchio 2007). These studies of bias have found the panel-derived CC method to be remarkably accurate when compared to data-driven assignments or rankings and ultimately provide adequate assessments of wetland condition (Gianopulos 2014). 
Regardless of CC value subjectivity, Floristic Quality Indices are "human concepts" that have proven to be effective indicators of vegetation condition and are successful ecological assessment tools for detecting disturbance in wetlands (Bourdaghs et al. 2006, USEPA 2002a).

\subsection{Objective}

The majority of FQI applications have focused on monitoring natural and anthropogenic disturbance impacts on naturally occurring wetlands. However, with the increasing number of wetland restoration activities in the United States, there is a rising demand for rapid assessment methods of restored wetland condition and performance. To date, few FQI studies have assessed the condition of created or nourished wetlands. In 2012, Cretini et al. successfully used their modified FQI to assess vegetation condition in a managed system (hydrologic alteration). However, the immediate need is to establish the use and suitability of an FQI for evaluating the condition and evolution of created wetlands, and to ultimately link condition to key wetland structure and function metrics. The purpose of this study is to identify and apply a biological index that uses monitoring data to evaluate condition, performance (related to ideal ranges or targets), and resilience of restored wetlands, and compare those wetlands to naturally occurring reference wetlands. Validating the use of these traditional FQI applications for restored wetland monitoring and evaluations are requisite for future remote sensing-based FQI methods. 


\section{Methods}

\subsection{Study sites}

Three study sites were utilized in this project. All sites consist of CWPPRA projects and surrounding areas (Figure 1). The first site, the Sabine Refuge Marsh Creation (CS-28) project and reference areas, consists primarily of intermediate and brackish wetlands that are located west of Hackberry, Louisiana. Hurricanes and canal building between 1956 and 1978 caused severe land loss in the area (Miller 2014). The Sabine restoration effort consists of five separate dredging cycles and creation sites (ranging in size from 125 to 230 acres) within an area of approximately 2,850 acres of open water. The creation sites, known as Cycles 1-5, were constructed in 2002, 2010, 2007, 2014, and 2015, respectively. At the time of sampling, only Cycles 1 (north) and 3 (south) contained vegetation, or vegetation survey data, so Cycles 2, 4, and 5 were not included in this study. Cycles 1 and 3 were constructed to an initial height of +2.7 to $+3.1 \mathrm{ft}$ North American Vertical Datum 1988 (NAVD88, Geoid 99) and allowed to consolidate and desiccate to a final target elevation of approximately +1.2 $\mathrm{ft}$ NAVD88 (Sharp 2003 and Miller 2014). After material consolidation and colonization of emergent vegetation, the containment dikes were breached to allow for hydrologic and fisheries access. The Cycles differ in that Cycle 1 was planted with 36,00o Spartina alterniflora plants around the perimeter and along the hydrologic and fish access channels (Miller 2014). Meandering and curving trenasses were also constructed within Cycle 1 (Sharp 2003). Conversely, vegetation and hydrology were allowed to occur naturally in Cycle 3.

The second site, Atchafalaya Big Island Mining (AT-03), consists of fresh water wetlands that are located southwest of Morgan City, Louisiana, within the Atchafalaya River Delta. The purpose of AT-03 was to enhance natural-delta-building processes by creating an avenue for sediment transport to areas north and west of the initial Big Island location (Curole 2003). In 1998, approximately 3.3 million cubic yards (cu yd) of material dredged from the Atchafalaya River was pumped into placement areas, at elevations between $+3.27 \mathrm{ft}$ and $+1.77 \mathrm{ft} \mathrm{NAVD88}$, and allowed to consolidate and desiccate to a final target elevation of +1.3 ft NAVD88 (Brown, Cunningham and Gannuch Inc. 1998), creating approximately 920 acres of new wetlands. Additionally, a secondary distributary channel, with four smaller tertiary channels, was constructed to emulate an emerging delta (Curole 2003). It was estimated that this restoration effort 
would provide approximately 2,000 acres of wetland gains over the course of the project lifespan (LCWCRTF 2002).

The third site, Little Lake Marsh Creation (BA-37), consists primarily of intermediate and brackish marsh (with recent transition to saline marsh along the southern fringe) located east of Cutoff, Louisiana. The project area consists of rapidly degrading Little Lake shoreline and Bayou L'Ours Ridge, which are protecting approximately 3,000 acres of fragile interior marshes (LCWCRTF 2015b). Shoreline erosion, subsidence, and channel construction in the Little Lake mapping unit has resulted in the loss of approximately 53\% of total wetlands from 1932 to 1990 (NMFS 2001). In 2007 , in an attempt to slow the erosion rate, material was hydraulically dredged from the bottom of Little Lake and pumped to the project fill area to create and nourish approximately 920 acres of marsh to an average fill elevation target of +2.1 feet NAVD88 (Louisiana Office of Coastal Protection and Restoration 2009). Within the first growing season after consolidation (2007), the created platform was vegetated with approximately 17,000 plugs of Spartina altermiflora (LCWCRTF 2015b).

\subsection{Assessment units}

Reference wetland sites serve as standards against which others are evaluated, and therefore they are critical components of all biological assessments (USEPA 2002a). Selection of appropriate or representative reference sites can be difficult; the use of multiple sites and scales can overcome some of the challenges of defining a reference standard for evaluating restoration performance (Matthews et al. 2009).

The assessment units used in this study consist of three varying scales (Figure 1); the Project, Project Reference (PR), and Subwatershed Reference (SR) units. The Project units consist of the pre-defined CWPPRA project boundaries. The PR units consist of CWPPRA established reference sites; existing or nearby wetlands that represent natural system processes and conditions. An example is the Atchafalaya study site's PR unit, which consists of the Wax Lake Delta (WLD). The WLD is a bayhead delta at the outfall of the Wax Lake Outlet, an artificial diversion of the Atchafalaya River (Carle 2013). Though the WLD and Atchafalaya Delta are both pro-grading deltas, the WLD is developing "naturally," while some of the islands within the Atchafalaya Delta were constructed (but receive significant riverine inputs). The SR units consist of generalized hydrologic units (HUC10) that are intersected with corresponding vegetation zones (Sasser et al. 2014) to represent natural wetland conditions and trajectories within larger watershed segments. 
Figure 1. Location map of study areas (Sabine, Little Lake, and Atchafalaya), assessment units (Project, Project Reference, and Subwatershed Reference), and data collection sites.

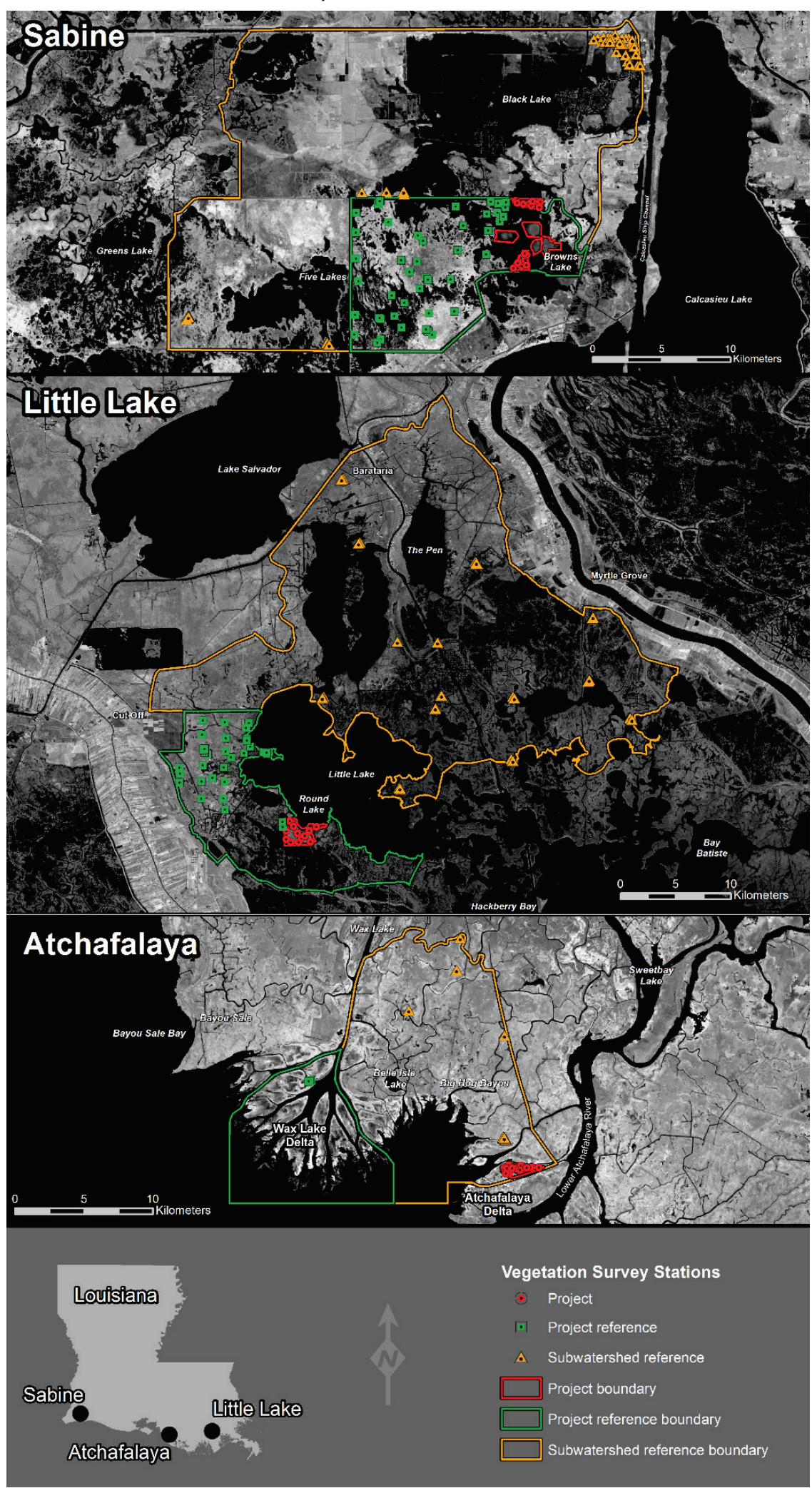




\subsection{Vegetation survey data}

Vegetation was surveyed at all Project, PR, and SR stations. Where available, this study used existing CWPPRA and Coastwide Reference Monitoring Stations (CRMS) vegetation data and locations, otherwise new survey stations were created uniformly along existing elevation transects. The CWPPRA monitoring program established standardized methods for monitoring variables that are useful in determining the performance of wetland restoration projects. Though those methods have not included FQI assessments in their monitoring approach. The vegetation monitoring component of CWPPRA collects species composition, relative abundance, and aboveground biomass data (Steyer and Stewart 1992). Vegetation data are typically collected more frequently early in a project's life (yearly), and less frequently (every 3-5 years) as a project nears the end of its anticipated lifespan (CWPPRA projects are typically designed and constructed for 20-year lifespans). Similarly, CRMS is a network of 392 monitoring sites in coastal Louisiana that is used to collect, process, and analyze physical, chemical, biological, and geospatial data to characterize coastal wetland landscapes inside and outside of CWPPRA projects (Cretini et al. 2011). Within the CRMS program, emergent vegetation are surveyed annually during the period of peak biomass (Folse et al. 2014). All existing vegetation data from CWPPRA and CRMS stations were acquired for all Project, PR, and SR sites. For new data collections, vegetation species composition and percent cover were collected from within $0.25 \mathrm{~m}^{2}$ quadrats at each project sample site during periods of peak biomass in 2014 and 2015 .

\subsection{Floristic quality index}

Though the standard FQI does not include invasive species, more recent iterations of the FQI use these opportunistic species as indicators of disturbance. These inclusions are driven by research showing strong correlations between invasive species richness and human activity, hydrologic impairments, and floristic index scores (Ervin et al. 2006). The standard FQI also uses the number of native species as an abundance measure. However, some existing restoration monitoring systems do not collect abundance values; rather, the systems collect percent cover values as part of the systems' monitoring protocol (Folse et al. 2014). In 2011, a modified FQI, which incorporates invasive species, percent cover values, and accounts for total percent cover and overlapping canopies, was developed for coastal Louisiana (Cretini et al. 2012). This index uses a two- 
pronged approach to account for sample units with vegetation cover that is less than or equal to $100 \%$ or is greater than $100 \%$ (overlapping canopies). If the sum of species covers within a sample unit at time $t$ is less than or equal to 100, the applicable formula is as follows:

$$
\mathrm{FQI}_{\bmod t}=\left(\frac{\sum\left(\operatorname{COVER}_{i t} \times \mathrm{CC}_{i}\right)}{100}\right) \times 10,
$$

where FQI $\bmod t$ is the modified floristic quality index (unitless), COVER it is the percent cover (\%) for species $i$ at a sample unit, within a sample site, at time $t$, and $\mathrm{CC}_{i}$ is the Coefficient of Conservatism for species $i$ (Table 1 ).

By using 100 in the denominator (instead of the actual sum of species covers), differentiation between wetlands of similar composition (e.g., vigorous wetlands) can be made using normalized biomass (estimated through cover) (Cretini et al. 2012). For consistency with other CRMS and CWPPRA metrics and indices, the FQI values are multiplied by 10 to scale the scores from o to 100 (Cretini et al. 2011).

If the sum of species covers within a sample unit at time $t$ is greater than 100 , the applicable formula is:

$$
\mathrm{FQI}_{\bmod t}=\left(\frac{\sum\left(\mathrm{COVER}_{i t} \times \mathrm{CC}_{i}\right)}{\sum\left(\mathrm{TOTAL} \mathrm{COVER}_{t}\right)}\right) \times 10,
$$

where TOTAL COVER $\mathrm{t}_{t}$ refers to the percent cumulative species cover (expressed as a percentage) within a sample unit (Cretini et al. 2012).

FQI score can provide measurements of vegetation condition and maturity. Low FQI values can be indicative of early successional vegetation communities, highly disturbed or early post-disturbance evolution, or other presses or pulses that are negatively impacting natural or managed wetlands. Conversely, high FQI values are more typical in mature, stable, and undisturbed wetlands.

For all established CWPPRA and CRMS stations within the Project, PR and SR assessment units, the CRMS Data Download service was used to acquire station-specific FQI data from 1997 to 2015 (Table 2) (CPRA 2016). These data were amended with vegetation surveys that were performed as part of this study (surveys conducted in 2014 and 2015). For existing and newly generated data, the CC values were applied and FQI $\mathrm{Imod}_{\mathrm{d}}$ 
was calculated for each vegetation station within the Sabine, Atchafalaya, and Little Lake Project, PR, and SR areas, using the Louisiana list and equations (Equations. 2 and 3, incorporating invasive species) developed by Cretini et al. (2011 and 2012). For species not on the Louisiana Coefficient of Conservatism list, established values from regional lists or neighboring states were used in conjunction with best judgement (Herman et al. 2006, Mortellaro et al. 2012, Gianopulos 2014). 


\section{Results and discussion}

There were a total of 559 vegetation stations used in this study (Table 2), the majority consisting of CWPPRA and CRMS monitoring stations. The Sabine study site consisted of 45, 125, and 68 vegetation stations (238 total) in the Project, PR, and SR units, respectively. The Atchafalaya study site consisted of 42, 15, and 49 vegetation stations (106 total) in the Project, PR, and SR units, respectively. The Little Lake study site consisted of 30, 36, and 149 vegetation stations (215 total) in the Project, PR, and SR units, respectively. Vegetation surveys for all study sites began in the 1990s, but the number and frequency of surveys varied within and across assessment units (Table 2). Generally, fewer surveys were performed in the first half of the period of analyses (1997-2015), and increased in the second half. The CWPPRA and CRMS-based vegetation data were supplemented with surveys within the Project units in 2014 and 2015.

\subsection{Community descriptions}

\subsubsection{Sabine vegetation}

Historically, vegetation survey data have been used to identify the presence of and track changes in vegetative species and communities over time. Miller (2014) describes a 1968 to 1988 shift in the CWPPRA Sabine project area vegetation community from intermediate and fresh dominated marsh species to more brackish species, including Spartina patens (saltmeadow cordgrass), Schoenoplectus americanus (bulrush), and Schoenoplectus robustus (saltmarsh bulrush).

Figure 2 shows the average percent cover by species for all stations within assessment units by year. The figure also groups and color codes all species based on CC values. There were 85 different plant species observed across all Sabine units and stations from 1997 to 2015. Species with cover values $<3 \%$ in a given year were categorized as "other." Within the Project assessment unit, Cycle 1 was constructed in 2002 and its edges were planted with Spartina alterniflora. The Cycle vegetated quickly and by the first vegetation survey (2004) Spartina alterniflora accounted for $57.5 \%$ of a total cover of 59.5\%. Hurricanes Lili (Category 1 storm, October 3, 2002) and Rita (Category 3 storm, September 24, 2005) significantly impacted vegetation communities along the central and western portions of coastal Louisiana. Hurricane Rita reduced the percent cover within Project sites to 
$1.8 \%$ in 2005 , but those sites recovered to $90 \%$ and $81.5 \%$ cover by 2006 and 2007, respectively. Spartina alterniflora remained the dominant species during this recovery, accounting for $90 \%$ and $76.6 \%$ of the total cover, respectively. By 2008, the Spartina alterniflora monoculture within the Project sites began to shift to a vegetative assemblage of common $(\mathrm{CC}=$ 7-8) and dominant $(\mathrm{CC}=9-10)$ species. This was due in part to the construction (2007) and natural colonization of Cycle 3. From 2011 to 2015, the typical vegetation profile for Project sites had total cover values between $75 \%$ and $87 \%$, and consisted primarily of Spartina alterniflora, Distichlis spicata, Schoenoplectus robustus, Borrichia frutescens, Iva frutescens, and nominal percentages of "other" species.

Table 2. Number of vegetation survey stations within each study site and assessment unit.

\begin{tabular}{|c|c|c|c|c|c|c|c|c|c|}
\hline \multirow[b]{2}{*}{ Date } & \multicolumn{3}{|c|}{ Sabine } & \multicolumn{3}{|c|}{ Atchafalaya } & \multicolumn{3}{|c|}{ Little Lake } \\
\hline & Project & $\begin{array}{c}\text { Project } \\
\text { Reference }\end{array}$ & $\begin{array}{c}\text { Subwatershed } \\
\text { Reference }\end{array}$ & Project & $\begin{array}{c}\text { Project } \\
\text { Reference }\end{array}$ & $\begin{array}{c}\text { Subwatershed } \\
\text { Reference }\end{array}$ & Project & $\begin{array}{c}\text { Project } \\
\text { Reference }\end{array}$ & $\begin{array}{c}\text { Subwatershed } \\
\text { Reference }\end{array}$ \\
\hline 1997 & 0 & 0 & 45 & 0 & 0 & 4 & 0 & 0 & 0 \\
\hline 1998 & 0 & 0 & 0 & 0 & 0 & 0 & 0 & 0 & 0 \\
\hline 1999 & 0 & 58 & 5 & 20 & 0 & 0 & 0 & 17 & 0 \\
\hline 2000 & 0 & 0 & 0 & 0 & 0 & 0 & 0 & 17 & 0 \\
\hline 2001 & 0 & 17 & 0 & 0 & 0 & 0 & 0 & 0 & 0 \\
\hline 2002 & 0 & 17 & 0 & 17 & 0 & 0 & 0 & 17 & 0 \\
\hline 2003 & 0 & 0 & 0 & 0 & 0 & 0 & 0 & 0 & 0 \\
\hline 2004 & 14 & 72 & 2 & 0 & 0 & 0 & 0 & 0 & 0 \\
\hline 2005 & 6 & 10 & 0 & 0 & 0 & 0 & 0 & 17 & 0 \\
\hline 2006 & 7 & 57 & 10 & 0 & 0 & 10 & 0 & 10 & 60 \\
\hline 2007 & 7 & 60 & 13 & 17 & 10 & 46 & 0 & 10 & 80 \\
\hline 2008 & 12 & 60 & 16 & 0 & 10 & 46 & 10 & 27 & 80 \\
\hline 2009 & 10 & 50 & 16 & 0 & 10 & 48 & 10 & 10 & 80 \\
\hline 2010 & 22 & 69 & 20 & 0 & 10 & 49 & 9 & 10 & 80 \\
\hline 2011 & 10 & 50 & 18 & 0 & 10 & 49 & 9 & 10 & 80 \\
\hline 2012 & 26 & 68 & 15 & 0 & 10 & 47 & 8 & 27 & 80 \\
\hline 2013 & 10 & 50 & 15 & 0 & 9 & 42 & 8 & 10 & 80 \\
\hline 2014 & 26 & 70 & 15 & 12 & 12 & 46 & 20 & 13 & 80 \\
\hline 2015 & 10 & 50 & 16 & 20 & 13 & 44 & 12 & 12 & 80 \\
\hline $\begin{array}{c}\text { Total } \\
\text { Stations }\end{array}$ & 45 & 125 & 68 & 42 & 15 & 49 & 30 & 36 & 149 \\
\hline
\end{tabular}


The first vegetation surveys in the Sabine PR assessment unit occurred in 1999 and exhibited a total of $88.6 \%$ vegetation cover. The PR sites consisted primarily of Spartina patens (14.9\%), Distichlis spicata (8.8\%), Schoenoplectus americanus (7.8\%), Schoenoplectus robustus (7.4\%), and the "other" class, which consisted of 22 species and accounted for $26.1 \%$ of the cover. By 2001 and 2002, the PR sites were dominated by Schoenoplectus americanus and Distichlis spicata, with some lower percentages of Spartina patens and Paspalum vaginatum (seashore paspalum). By the 2005 surveys, the average total cover per site decreased to $44.4 \%$ and consisted of only two species, Spartina patens and Paspalum vaginatum. This change in cover was directly related to hurricane impacts. From 2006 to 2015, the PR sites exhibited a slow recovery and reestablishment of vegetation, with higher percentages of the "other" class, followed shortly by increasing percentages of disturbance species $(\mathrm{CC}=1-$ 3 ) and more recently by vigorous wetland species $(\mathrm{CC}=4-6)$.

In 1997, the SR stations consisted primarily of Schoenoplectus californicus, (19.1\%), Spartina patens (15.4\%), and Paspalum vaginatum (7.7\%). The SR stations in 1997 consisted of 31 species that were categorized as "other," accounting for $20.9 \%$ of the total cover. The dominant species persisted throughout the period of study, but they were occasionally equaled or surpassed in cover by Iva frutescens (Jesuit's bark; max 14\%), Distichlis spicata (Coastal Salt Grass; max 11.9\%), and Leptochloa fusca (Malabar sprangletop; max 22.1\%).

For the Sabine sites, the Project unit experienced rapid vegetation establishment followed by a transition to higher diversity and colonization by common and dominant species. The PR and SR units were dominated by common and dominant species prior to Hurricane Rita. However, the PR unit transitioned to dominant with vigorous wetland species while the SR unit transitioned to assemblages with higher numbers of disturbance species with higher percentages of cover.

\subsubsection{Atchafalaya vegetation}

Historically, two general herbaceous vegetation associations, Sagittaria and Typha, have dominated the natural Atchafalaya Delta islands (Johnson et al. 1985). The Sagittaria association, which typically occurs at the lowest intertidal elevations, consists of Sagittaria latifolia (duckpotato), Sagittaria platyphylla (delta duckpotato), and Schoenoplectus americanus (previously known as Scirpus americanus, 
three-cornered grass) (Curole and Babin 2010). The Typha association, which consists of Typha latifolia (broadleaf cattail), Cyperus difformis (cyperus), Eleocharis spp. (spikerush), Scirpus validus (softstem bulrush), and Ammannia coccinea (ammannia), typically occurs at intermediate elevations (Curole and Babin 2010).

Figure 3 shows the average percent cover by species for all stations within assessment units by year for the Atchafalaya study site. There were 112 unique plant species observed across all units and stations from 1999 to 2015. The Atchafalaya Big Island mining wetlands were constructed in 1998 and the first Project vegetation surveys were performed in 1999. The total cover for the first survey was $78.5 \%$ and dominated by disturbance and vigorous wetland species. Those species included Leptochloa panicoides, Nelumbo lutea, and Potamogeton nodosus, each accounting for 10.3\% cover, as well as Sphenoclea zeylanica, Heteranthera dubia, and Myriophyllum spicatum, each accounting for slightly more than $6 \%$ cover. In 1999, the sites also consisted of 20 "other" class species, accounting for $15.3 \%$ of the total cover. The effects of Hurricane Lili are observed in the 2002 survey data, which show the total cover was reduced to $35.3 \%$. By the 2007 survey, the Project area total percent cover increased to pre-hurricane levels, and the dominant species remained invasive and in rigorous communities. Though this trend of invasive and rigorous species continued, the dominant species shifted to Typha latifolia (24.2\% cover), Zizaniopsis miliacea (22.2\%), Ludwigia leptocarpa (13.4\%), and Bidens laevis (11.2\%) in 2014, then to Heteranthera (19.5\%), Nelumbo lutea (11.5\%), Hypoxis sessilis (11.0\%), and Colocasia esculenta (10.4\%) by 2015 .

The PR area, which consists solely of the Wax Lake Delta CRMS survey sites, began collecting annual data in 2007. The cover and dominant species within the PR sites remained consistent from 2007-2012, with the total percentages ranging from $79.1 \%$ to $91.1 \%$ per year. The dominant species during this period were in the invasive and rigorous communities and consisted of Alternanthera philoxeroides, Bidens laevis, Colocasia esculenta, Ludwigia peploides, Polygonum punctatum, and Sesbania drummondii. The 2013 survey shows that the majority of the total cover was dominated by the invasive Colocasia esculenta. This shift in vegetation could be the result of disturbance events, particularly the major Atchafalaya River flood in 2011 and Hurricane Isaac (Category 1), which made landfall on August 28, 2012. The 2014 and 2015 surveys show sites 
that increased in cover by rigorous species, led by Sagittaria latifolia, with $19.7 \%$ and $26.6 \%$ of the total cover for each year, respectively.

The Atchafalaya SR assessment unit consists of longstanding mainland fresh marsh sites. The SR sites were first surveyed in 2006, and it is theorized that the number of dominant invasive species present are indicative of disturbance conditions that would be expected after Hurricane Rita. From 2007-2015, the SR vegetation remained consistent, with the total percentages ranging from $70.0 \%$ to $86.8 \%$ cover. Approximately half of the average total cover consisted of the "other" class species. This is typical for fresh marsh, which has the greatest plant diversity of any marsh type (Lester et al. 2005). This period, which was dominated by the dominant species Panicum hemitomon and Spartina patens; the common species Leersia hexandra and Spartina cynosuroides; the rigorous species Zizaniopsis miliacea, Nelumbo lutea, and Phragmites australis; and the disturbance species Bidens laevis and Vigna luteola; rarely had a single species with cover values greater than $10 \%$.

The vegetation survey data show that the communities differed greatly between the Atchafalaya assessment units. These differences were primarily due to differences in elevation (Curole and Babin 2010), which were estimated at $1.35 \mathrm{ft}, 1.17 \mathrm{ft}$, and $2.15 \mathrm{ft}$ (NAVD88) for Atchafalaya Project, PR, and SR sites, respectively (2010 LiDAR data, CPRA 2012). The vegetative communities also differed due to varying age of marsh across all Atchafalaya assessment units. The Project and SR sites are relatively young deltaic marsh compared to long-established SR mainland marsh. Additionally, increasing establishment and cover of aquatic vegetation, like Nelumbo lutea, are the results of the constructed channels distributing sediment and building additional wetland area adjacent to the restored islands.

\subsubsection{Little Lake vegetation}

Since the 1950s, the Little Lake study area has varied from intermediate to brackish marsh, with a shift to higher salinity species (Spartina patens, Distichlis spicata, and Juncus roemerianus) in recent decades (GOTECH Inc. 2003). The Little Lake CWPPRA project (BA-37) was constructed in 2007 with both created and nourished wetlands in a highly subsiding and degrading landscape. Figure 4 shows the average percent cover by species for all stations within assessment units by year for the Little Lake study 
site. There were 126 unique plant species observed across all units and stations from 1999 to 2015.

The total cover for the first Little Lake Project survey, performed in 2008, was $77.0 \%$ and dominated by common and dominant wetland species. The dominant plants in 2008 consisted of Spartina patens (20.3\% cover), Spartina alterniflora (14.4\%), Cyperus filicinus (9.8\%), and Schoenoplectus americanus (7.6\%). These dominant species remained throughout the 2008 to 2015 period, with yearly or seasonal dominant occurrences of Paspalum vaginatum, Distichlis spicata, Sacciolepis striata, and the disturbance species Amaranthus australis, Setaria parviflora, and Vigna luteola. The percent cover for the "other" species ranged from $2.9 \%$ in 2008 to $25.8 \%$ in 2015 .

The PR area consists of brackish marsh located northwest of the Little Lake Project area. The PR survey stations consisted of Gulf Intracoastal Waterway (GIWW) to Clovelly Hydrologic Restoration (BA-02) CWPPRA project sample sites. The PR area is in close proximity to the Little Lake Project area, is typical of marsh condition in the Barataria Basin, and has ample vegetation survey data. The BA-02 project phases, which were constructed in 1997 and 2000, were intended to provide wetland stability through hydrologic restoration and shoreline protection. Two years after the first phase of BA-02, the vegetation within PR sites was common and dominant communities, consisting of Schoenoplectus (Reichenb.) Palla (bulrush, $18.0 \%$ cover), Spartina patens (15.3\%), Schoenoplectus robustus (13.3\%), and Spartina alterniflora (10.7\%). After the second phase of BA-02, there were shifts in vegetation to communities that were dominated by Spartina patens, Eleocharis cellulosa, Schoenoplectus americanus, and Ipomoea sagittata, with intermittent and moderate coverage by Kosteletzkya virginica, Juncus roemerianus, and Schoenoplectus pungens (common threesquare). During the BA-02 post construction period, the total vegetation cover ranged from $55.9 \%$ to $87.1 \%$, and the cover of the "other" class ranged from $12.9 \%$ to $34 \%$.

The SR area consisted of multiple CWPPRA survey sites BA-20, BA-23, and BA-39, as well as multiple CRMS stations. The vegetation surveys were conducted in the SR areas between 2006 and 2015 and show total average cover ranging from $74.4 \%$ to $87.6 \%$. The general vegetative communities present at these sites are consistent with those at the PR sites, except the SR survey sites contained higher counts and cover of 
disturbance species, and relatively higher percentages of cover from the "other" species.

The Little Lake Project sites were similar in total cover and dominant species to the PR and SR sites. However, the Project sites did contain lower percentages of cover from the "other" species, and typically had fewer disturbance species than both reference areas.

These vegetative surveys and community descriptions are typical for vegetation-based monitoring and assessments of restoration projects and performance. Plant species identification and cover values allow for the monitoring of project sites and for comparison to reference wetlands or other restoration projects. Shifts in vegetative species and/or cover are useful for identifying key disturbances, pulses and presses, and ultimately as indicators of wetland condition. However, additional metrics or indices would be helpful to complement interpreting and understanding shifts in vegetative communities and changes in percent cover.

Figure 2. Percent cover and CC values for species within the Sabine assessment units.
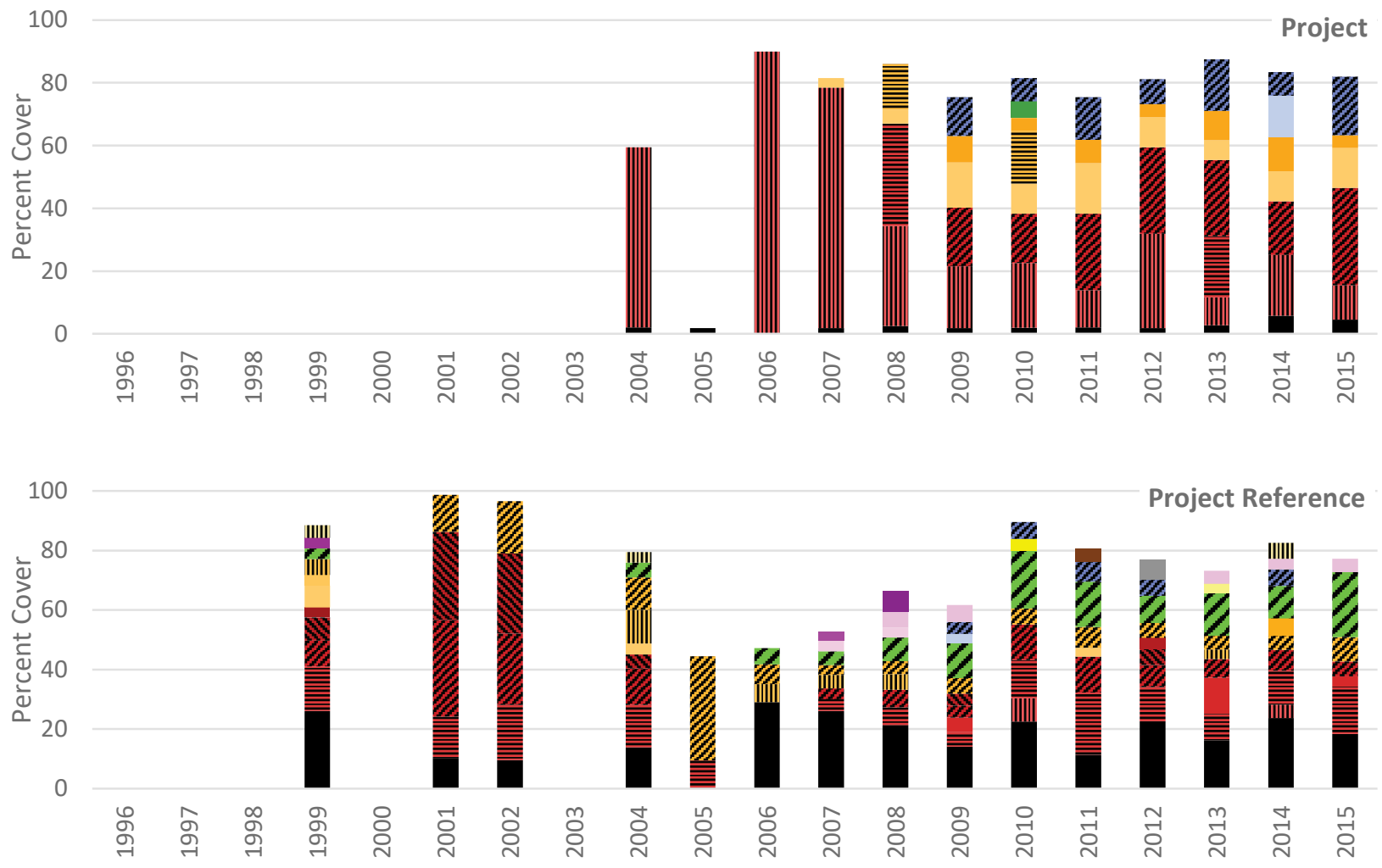

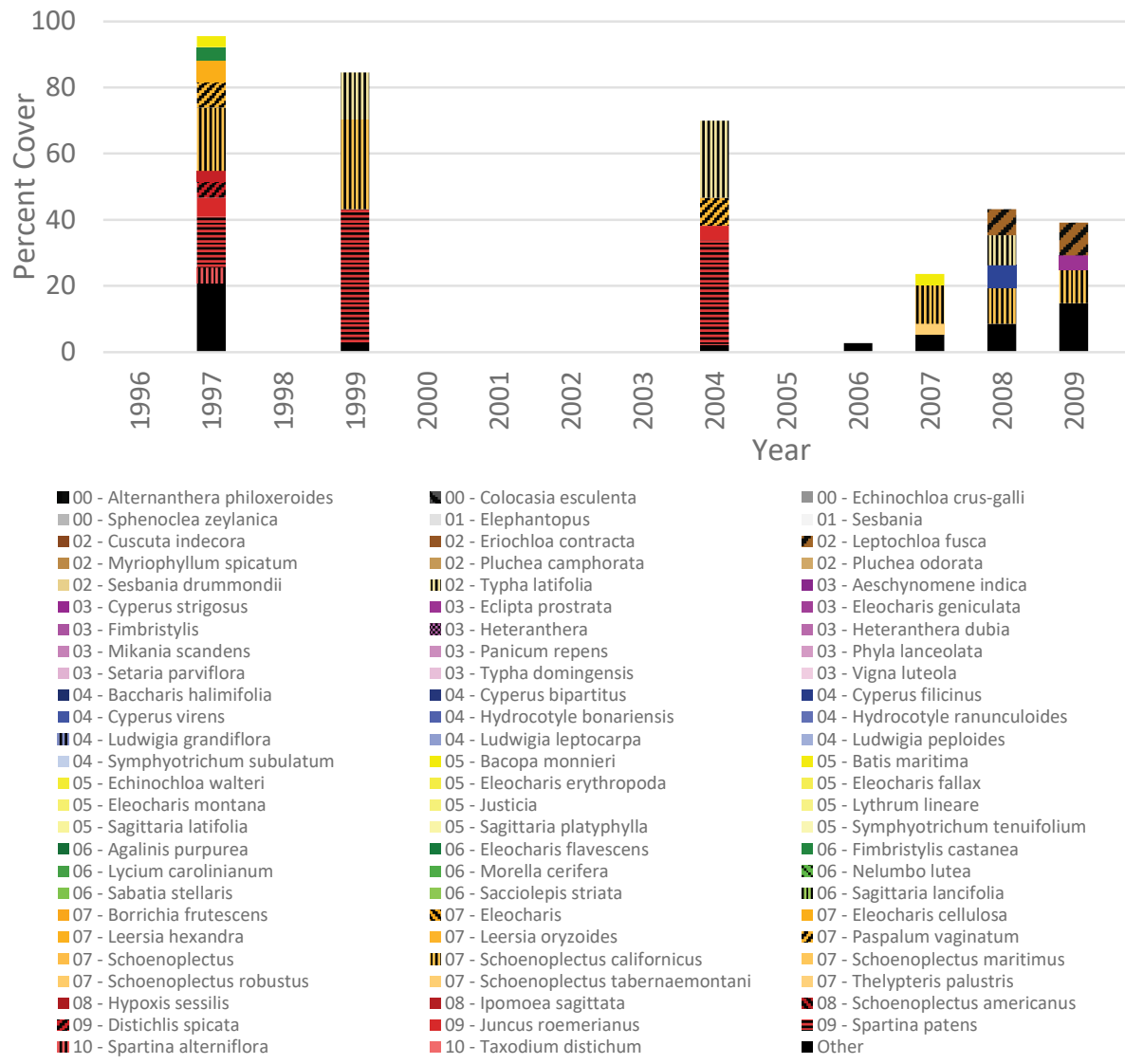

Subwatershed Reference

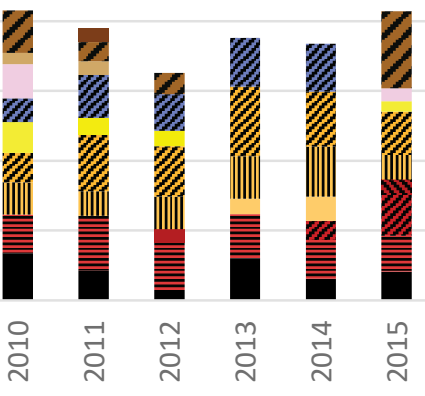

00 - Alternanthera philoxeroides

$$
\begin{aligned}
& \text { W0 } 00 \text { - Colocasia esculenta } \\
& 01 \text { - Elephantopus } \\
& \text { 02 - Eriochloa contracta } \\
& \text { w02 - Pluchea camphorata } \\
& \text { II } 02 \text { - Typha latifolia }
\end{aligned}
$$

- 03 - Eclipta prostrata

03 - Heteranthera

03 - Panicum repens

03 - Typha domingensis

- 04 - Cyperus bipartitus

- 04 - Hydrocotyle bonariensis

04 - Ludwigia leptocarpa

05 - Bacopa monnieri

05 - Eleocharis erythropoda

05 - Justicia

05 - Sagittaria platyphylla

- 06 - Eleocharis flavescens

- 06 - Morella cerifera

06 - Sacciolepis striata

a 07 - Eleocharis

$\mathbf{s} 07$ - Eleocharis
07 - Leersia oryzoides

II 07 - Schoenoplectus californicus

II 07 - Schoenoplectus californicus

08 - Ipomoea sagittata

- 09 - Juncus roemerianus

10 - Taxodium distichum

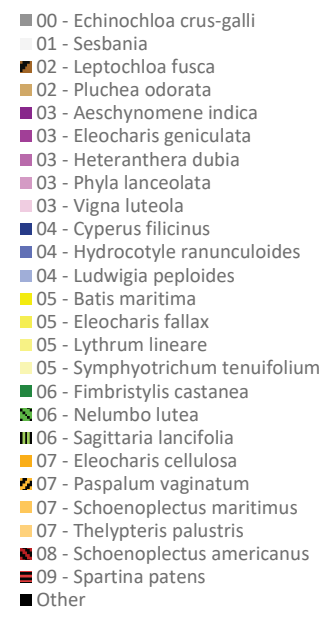

a0 - Eichhornia crassipes

02 - Amaranthus australis

02 - 02 tochlo panicoides

- 02 - Salix nigra

03 - Bidens laevis

- 03 - Eleocharis parvula

n 03 - Hydrocotyle umbellata

- 03 - Saccharum giganteum

- 04 - Ammannia latifolia

04 - Cyperus odoratus

Z04 - Iva frutescens

04 - Potamogeton nodosus

05 - Cicuta maculata

105 - Eleocharis macrostachya

05 - Polygonum punctatum

II 05 - Zizaniopsis miliacea

- 06 - Justicia americana

06 - Phragmites australis

- 06 - Scirpus americanus

- 07 - Kosteletzy virginica

- 07 - Kasticernicta virginica

三07- Salicornia depressa

07 - Schoenoplectus pungen

- 08 - Cladium mariscus

- 08 - Spartina cynosuroides

10 - Panicum hemitomon

Figure 3. Percent cover and CC values for species within the Atchafalaya assessment units.

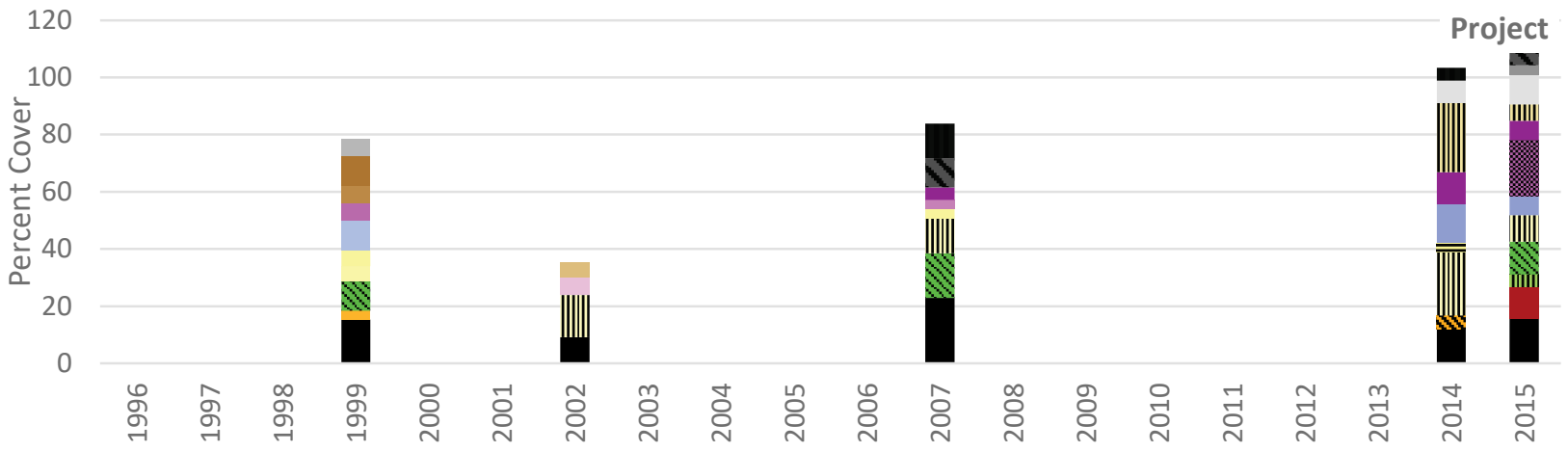




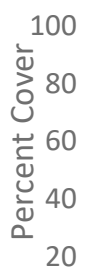

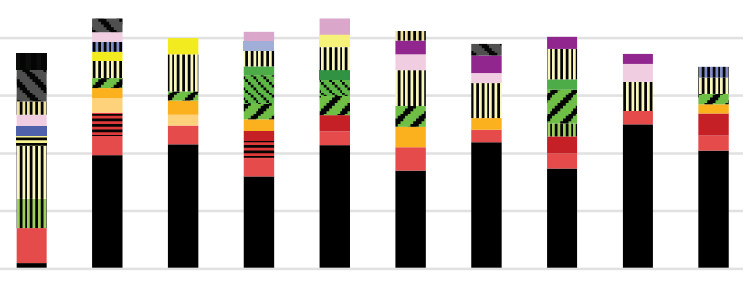

0

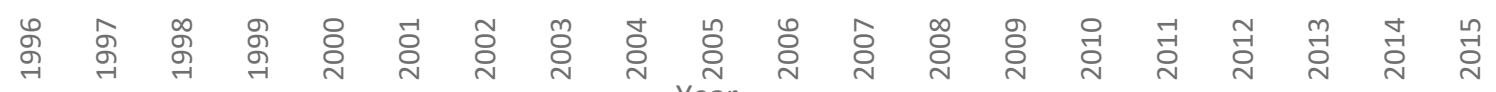

- 00 - Alternanthera philoxeroides

00 - Colocasia esculenta

00 - Sphenoclea zeylanica

- 02 - Cuscuta indecora

- 02 - Myriophyllum spicatum

02 - Sesbania drummondii

03 - Cyperus strigosus

03 - Fimbristylis

03 - Mikania scandens

03 - Setaria parviflora

04 - Baccharis halimifol

n 04 - Cyperus virens
II 04 - Ludwigia grandiflora

04 - Symphyotrichum subulatur

05 - Echinochloa walteri

05 - Eleocharis montana

05 - Sagittaria latifolia

- 06 - Agalinis purpurea

- 06 - Lycium carolinianum

- 06 - Sabatia stellaris

07 - Borrichia frutescens

- 07 - Leersia hexandra

07 - Schoenoplectus

07 - Schoenoplectus robustus

- 08 - Hypoxis sessilis

09 - Distichlis spicata

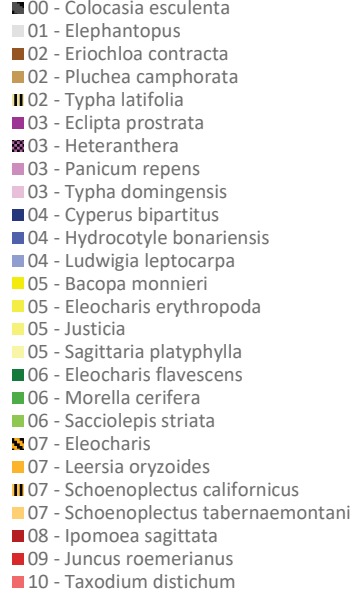

n 00 - Echinochloa crus-galli

01 - Sesbania

00 - Eichhornia crassipes

02 - Leptochloa fusca

03 - Aeschynomene indica

03 - Eleocharis geniculata

03 - Heteranthera dubia

03 - Phyla lanceolata

03 - Vigna luteola

03 - Vigna luteola

- 04 - Cyperus filicinus

- 04 - Hydrocotyle ranuncu
04 - Ludwigia peploides

05 - Batis maritima

05 - Eleocharis fallax

05 - Lythrum lineare

05 - Symphyotrichum tenuifolium

- 06 - Fimbristylis castanea

\$ 06 - Nelumbo lutea

III 06 - Sagittaria lancifolia.

07 - Eleocharis cellutia

07- Paspalum vaginatum

07 - Schoenoplectus maritimus

07 - Thelypteris palustris

08 - Schoenoplectus americanus

09 - Spartina patens

02 - Amaranthus australis

02 - Leptochloa panicoides

02 - Salix nigra

03 - Bidens laevis

03 - Eleocharis parvula

03 - Hydrocotyle umbellata

03 - Saccharum giganteum

04 - Ammannia latifolia

04 - Cyperus odoratus

a 04 - Iva frutescens

04 - Potamogeton nodosus

05 - Cicuta maculata

05 - Eleocharis macrostachya

=05-Polygonum punctatum

III 05 - Zizaniopsis miliacea.

06 - Justicia americana

- 06 - Phragmites australis

- 06 - Scirpus americanus.

07 - Kosteletzkya virginica

$\equiv 07$ - Salicornia depressa

07 Salicomilapressa

08 - Cladium mariscus

- 08 - Spartina nosurides

- 08 - Spartina cynosuroides

- Other

Figure 4. Percent cover and CC values for species within the Little Lake assessment units.
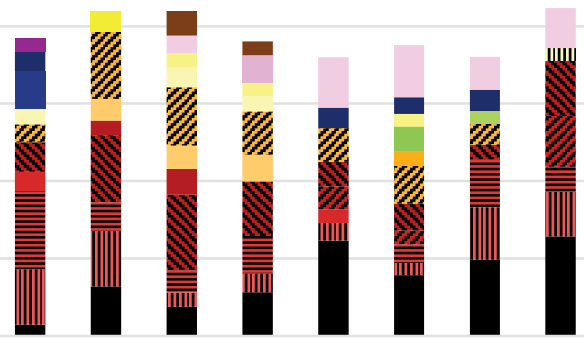

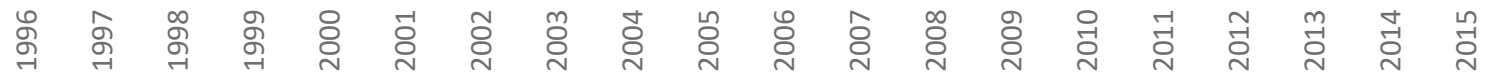

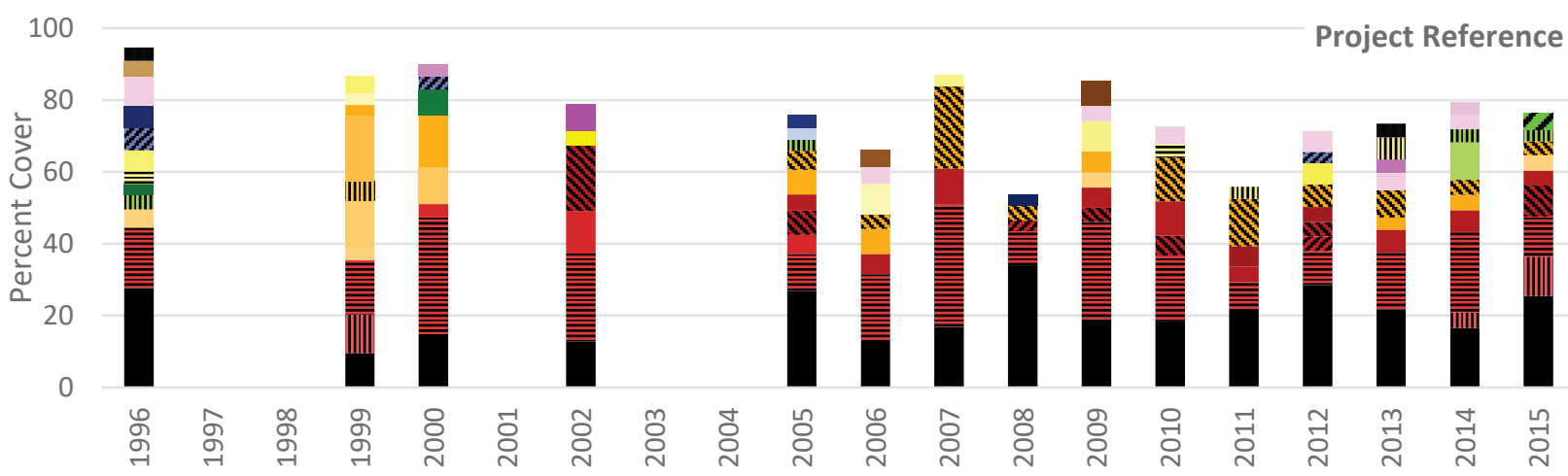




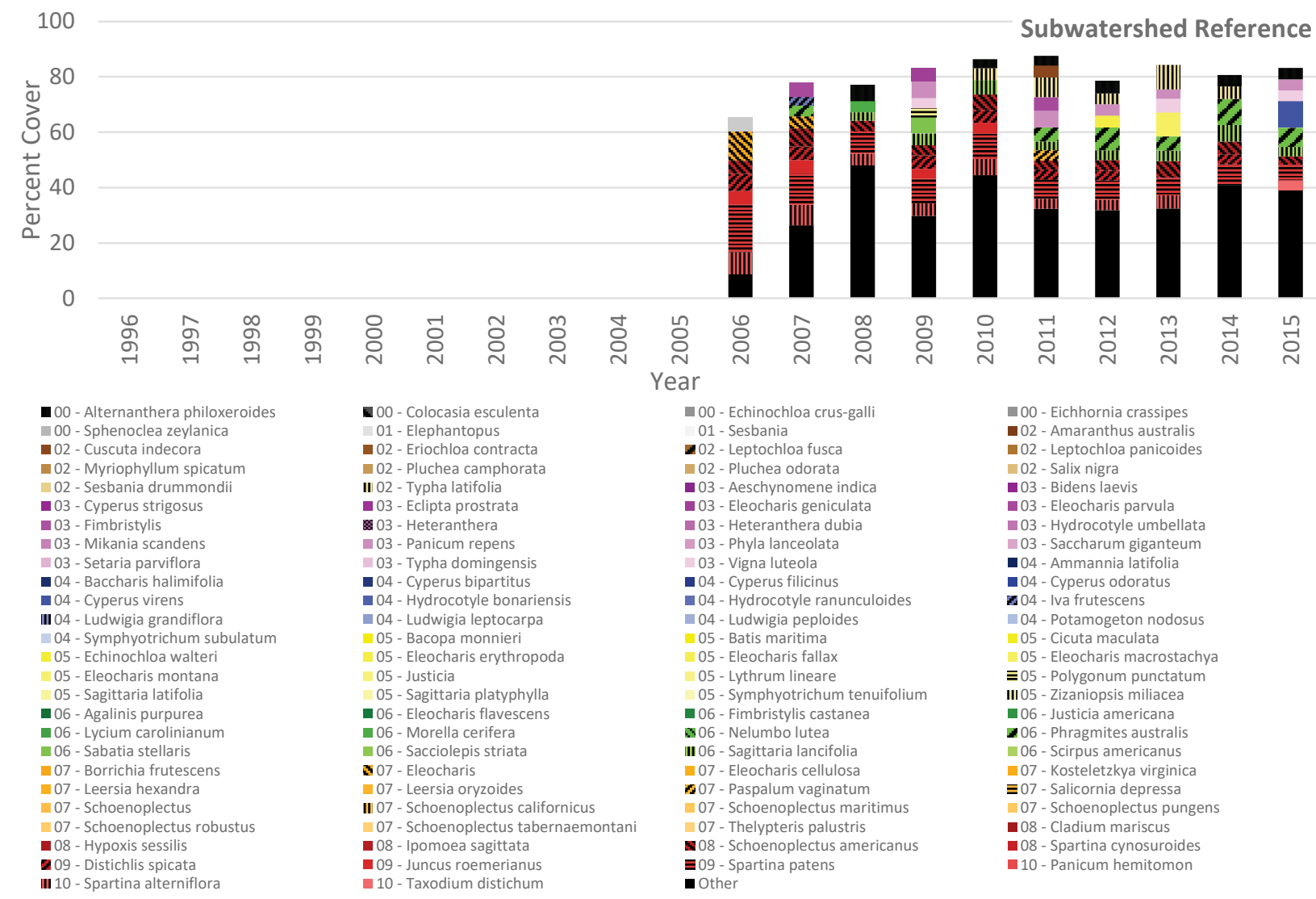

\subsection{Coefficients of conservatism}

The Coefficients of Conservatism (CC) is a value that indicates a plant's fidelity to specific habitat types and degree of ecological tolerance (Gianopulos 2014). CC values provide measures of wetland quality and are therefore useful indicators of wetland condition, and system pulses, presses, and disturbance events. Figure 5 illustrates the average Coefficient of Conservatism for all survey stations by study site assessment units. Figure 5 also shows the combined average $\mathrm{CC}$ values for all study sites (Sabine, Atchafalaya, and Little Lake combined), by assessment unit. The average CC values for the Project assessment units are 5.66, 4.27, 5.49, and 5.14 for the Sabine, Atchafalaya, Little Lake, and all study sites, respectively. The average CC values within the PR units were lower than the Project units but had similar trends across the study sites. The average $\mathrm{CC}$ values within the SR units were generally between the Project and PR values, except for the Atchafalaya study site, which registered its highest average $\mathrm{CC}$ value within the SR unit. This exception is likely due to the SR sites being located in longestablished mainland marsh, where the Project and PR wetlands are in relatively recently constructed/established marsh in higher energy environments. These overall findings are expected since fresh marsh, like 
those within the Atchafalaya study area, are more accommodating to a higher number of plant species, including invasive plants. Conversely, higher salinity levels in brackish and saline marshes, like those at Sabine and Little Lake, restrict the number of viable species and therefore are less prone to colonization by invasive and disturbance species.

Figure 5. Average $\mathrm{CC}$ for all survey stations within study site assessment units.

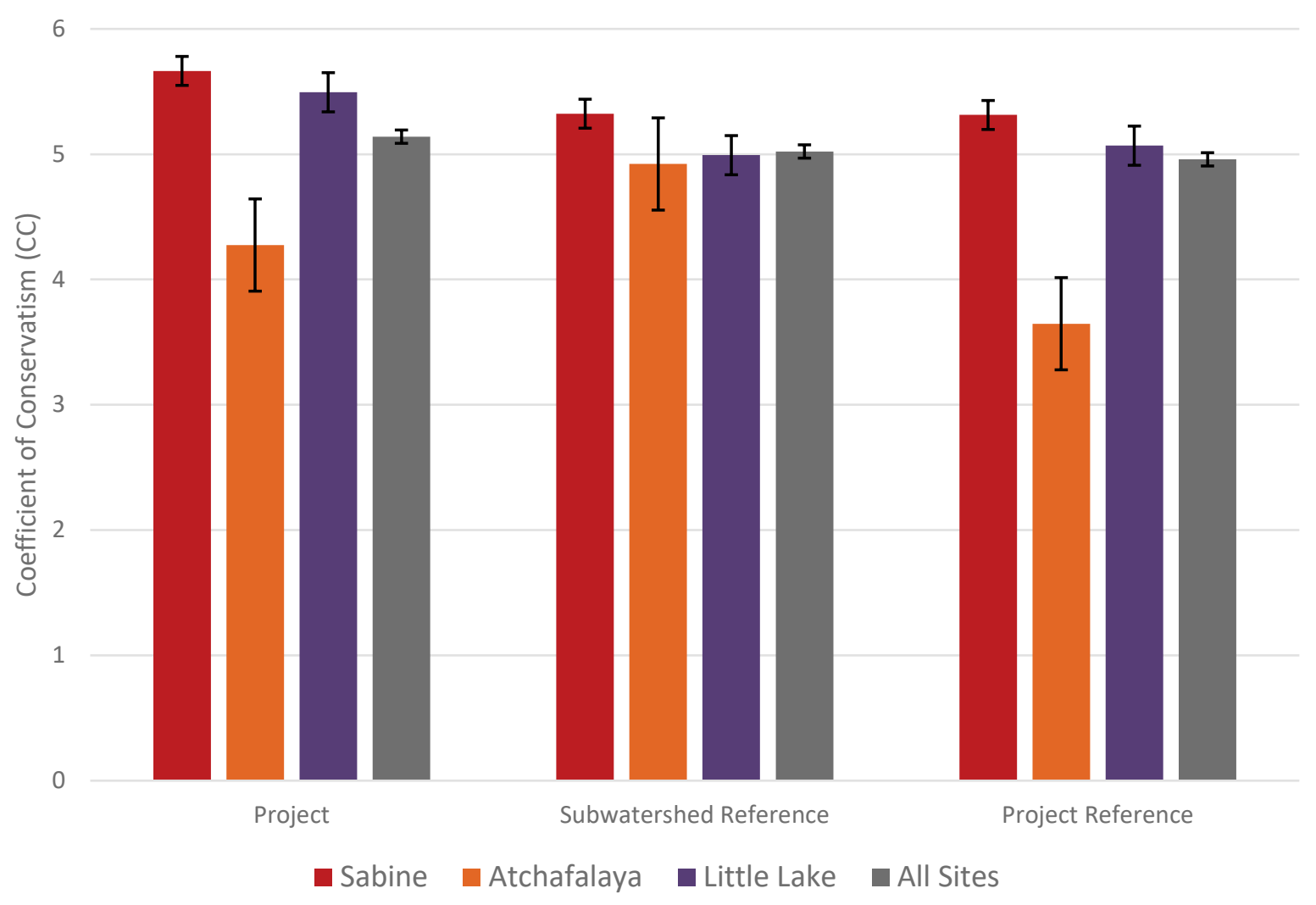

\subsection{Floristic quality}

\subsubsection{Sabine FQI}

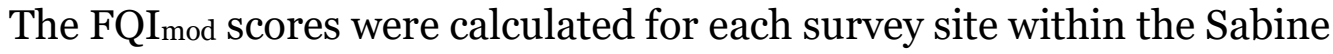
assessment units from 1997 to 2015 (Figure 6). The Project sites (red dots), consisting of Cycle 1 and Cycle 3, were first surveyed in 2003 (post construction of Cycle 1) and last surveyed in 2015. The PR sites (green squares) were surveyed from 1999 to 2015, and the SR sites (yellow triangles) were surveyed from 1997 to 2015. Trendlines (2nd order polynomial) within Figure 6 show the trends and trajectories of FQImod values across each assessment unit's period of analysis. The Subwatershed Reference unit data and trendline show a landscape with rapidly declining floristic quality. This is indicative of a system with degrading wetland 
function and corroborates previous studies that have shown significant wetland area and function loss due to hurricanes, saltwater intrusion, increased water fluctuations, and tidal scouring (Barras 2005, LCWCRTF 2002, and Miller 2014). The Project Reference unit data and trendline show a landscape that was on a declining trajectory but stabilized in 2007 and subsequently has had an increasing FQImod. The long-term degeneration that has occurred in this area is evident from 1999-2004 (Figure 6); however, a CWPPRA project aimed at restoring hydrologic connectivity was completed in the PR unit in 2001, and its impact can be observed in the increasing FQI mod scores from 2007 to 2015. The Project unit data and trendline show a landscape with early increasing floristic quality; however, the FQI scores have experienced a slight decreasing trend since 2012, which may be attributable to increased salinity levels and hurricane impacts. Though the PR unit is proximal to the Project unit, the effects of salinity may vary due to containment dikes and hydrologic alterations. The inset chart in Figure 6 shows the average salinity values measured at the Project CRMS station. The elevated salinity (upwards of 35 parts per thousand (ppt)) at the end of 2011 and effects from Hurricane Isaac (2012) may have impacted vegetation and FQI $I_{\text {mod }}$ scores between 2012 and 2015. The Project unit FQI mod data and trends are indicative of the rapid colonization and vegetative growth that are common in newly constructed wetlands. The Project unit average FQI mod score from 2010 to 2015 was approximately 80 . This coincides with the ideal range for Chenier Plain brackish marsh that was reported by Cretini et al. (2012) (Table 3). Since construction, the Project sites have primarily had higher floristic quality than both of the reference units.

Table 3. Preliminary ideal range for vegetation indices in Louisiana's principal geological settings. (Cretini et al. 2011)

\begin{tabular}{|l|l|l|}
\hline Geological setting & Habitat type & FQI $I_{\text {mod }}$ \\
\hline \multirow{4}{*}{ Inactive deltaic plain } & Fresh marsh & $>80$ \\
\cline { 2 - 3 } & Intermediate marsh & $>80$ \\
\cline { 2 - 3 } & Brackish marsh & $>80$ \\
\cline { 2 - 3 } & Saline marsh & $>80$ \\
\hline \multirow{4}{*}{ Active deltaic plain } & Fresh marsh & $>70$ \\
\cline { 2 - 3 } & Intermediate marsh & $>70$ \\
\hline \multirow{4}{*}{ Chenier plain } & Fresh marsh & $>80$ \\
\cline { 2 - 3 } & Intermediate marsh & $>80$ \\
\cline { 2 - 3 } & Brackish marsh & $>80$ \\
\cline { 2 - 3 } & Saline marsh & $>80$ \\
\hline
\end{tabular}


Figure 6. Floristic Quality Index ( $F Q I_{\text {mod }}$ ) scores for all survey stations within the Sabine assessment units by year. Vertical lines and inset chart provide tropical storm (TS) activity (wind speed miles per hour) and salinity data, respectively.

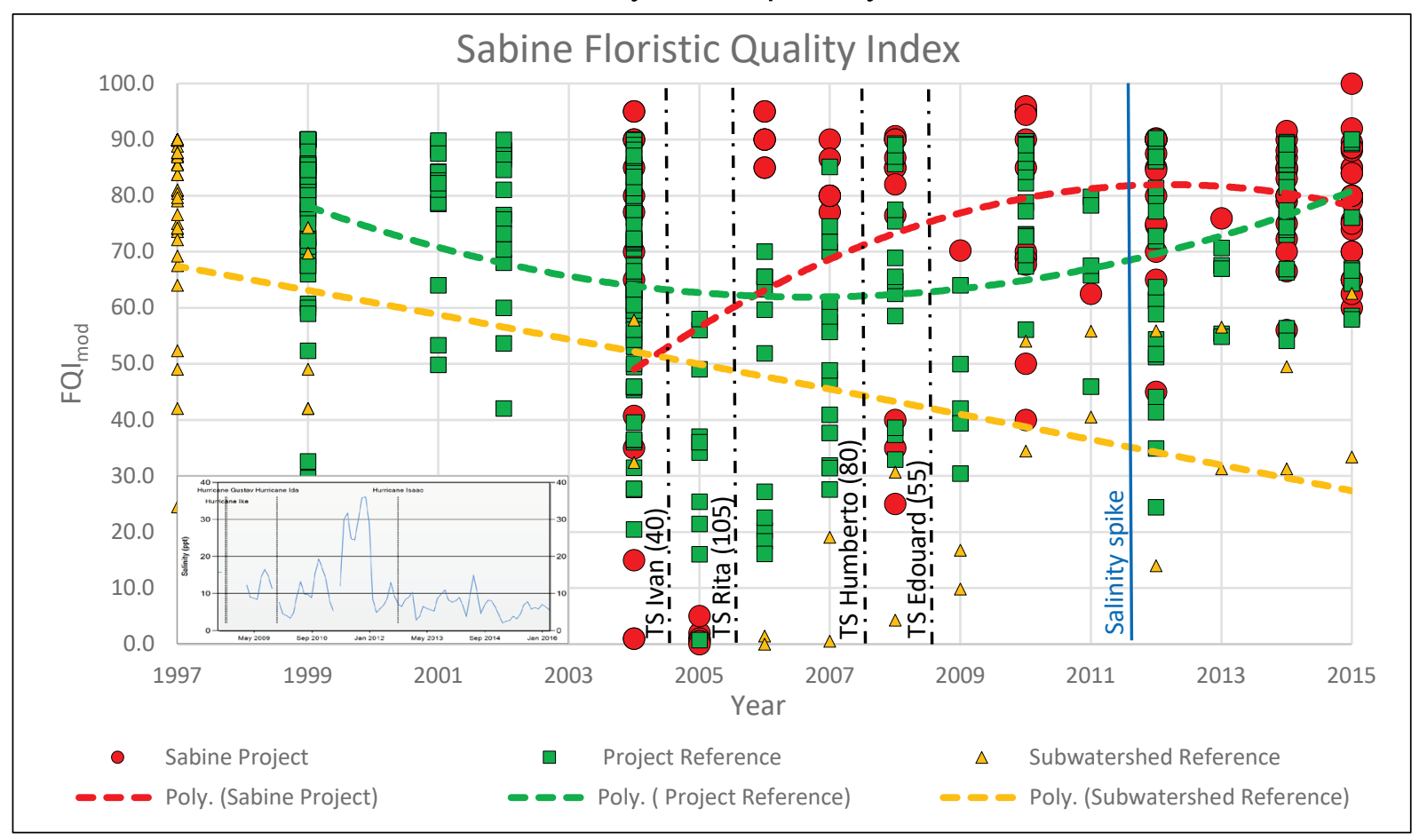

\subsubsection{Atchafalaya FQI}

The FQImod scores were calculated for each survey site within the Atchafalaya assessment units from 1997 to 2015 (Figure 7). The Project sites, represented by red dots, were first surveyed in 1999 (post construction of CWPPRA AT-03) and were last surveyed in 2015. The PR sites (green squares) were surveyed from 2007 to 2015, and the SR sites (yellow triangles) were surveyed from 1997 to 2015. Trendlines (2nd order polynomials) within Figure 7 show the trends and trajectories of FQImod values across each assessment unit's period of analysis. The Subwatershed Reference unit data show a slight positive trend in FQImod from 1997 to 2010, then a slight decreasing trend through 2015. The range in mean SR FQI $I_{\text {mod }}$ across the period of analysis is from approximately 39 to 45 . This is indicative of a system with highly stable wetlands and ecosystem function and corroborates previous studies that have shown the wetlands in close proximity to the lower Atchafalaya River to be some of the most stable and productive in coastal Louisiana (CWPPRA 2016). The Project Reference

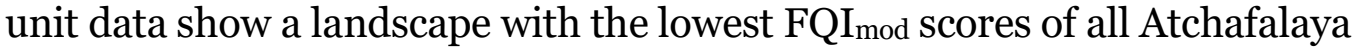
units. The trendline for the PR unit shows moderately declining FQI mod scores from 2007 to 2015 , and is indicative of early successional communities in a slowly pro-grading delta. The Project area wetlands were 
constructed in 1998, and by the first vegetation survey in 1999, the Project sites had a mean FQImod score of approximately 30 . This score is lower than the ideal range for fresh marsh in Louisiana's active Deltaic Plain, and lower than those at the mainland SR sites; however, it is reasonable in a highenergy riverine setting. The Project FQI mod scores show a moderately declining trend from 1999 to 2006. These conditions were probably influenced by Hurricanes Lili and Rita in 2002 and 2005, respectively. The inset chart in Figure 7 shows one spike in salinity as a result of Rita's storm surge. However, the magnitude and duration of the spike is relatively small and no salinity impacts are observed in subsequent FQI mod data. From 2007 to 2015, the Project FQImod scores show moderately increasing trends, and at current trajectories are outperforming the PR sites and may soon approach mainland SR site FQI mod scores. Some of the trendline breakpoints in Figure 7 occur around 2011. These are possible effects of the historic high Mississippi River flood that occurred in spring 2011, which could have introduced additional flooding stress to the PR and SR vegetation communities (Carle et al. 2013).

Figure 7. Floristic Quality Index ( $\left.F Q I_{m o d}\right)$ scores for all survey stations within the Atchafalaya assessment units by year. Vertical lines and inset chart provide tropical storm (TS) activity (wind speed miles per hour) and salinity data, respectively.

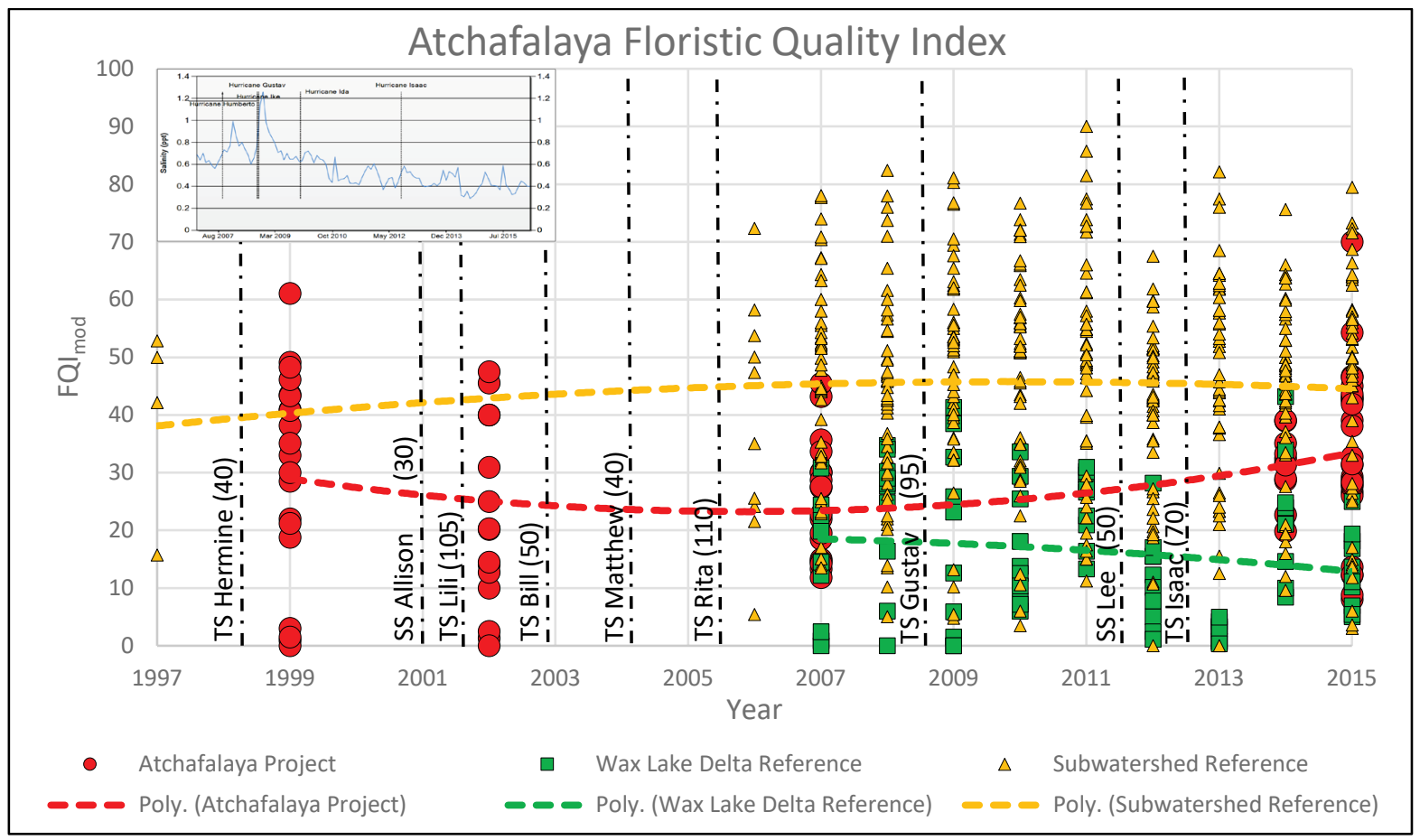




\subsubsection{Little Lake FQI}

The FQI mod scores were calculated for each survey site within the Little Lake assessment units from 1999 to 2015 (Figure 8). The Project sites, represented by red dots, were first surveyed in 2008 (post construction of CWPPRA BA-37) and were last surveyed in 2015. The PR sites (green squares) were surveyed from 1999 to 2015, and the SR sites (yellow triangles) were surveyed from 2006 to 2015. Similar to Figures 6 and 7 , Figure 8 shows the trendlines and trajectories of FQImod values for each assessment unit. The Subwatershed Reference unit data show a consistent FQImod score of approximately 70 from 2006 to 2011, then a slight decreasing trend through 2015. These scores are below the ideal range of 80 for brackish marsh in Louisiana's inactive Deltaic Plain (Table 3). The recent decreasing SR FQI mod scores are possibly the result of Hurricane Isaac (2012) impacts. The SR unit is one of substantial wetland deterioration, primarily as a result of saltwater intrusion and rapid subsidence; nevertheless, multiple hydrologic restoration projects (Naomi Outfall Management BA-O3c and Jonathan Davis Wetland Restoration BA-20) have been constructed in an attempt to help stabilize the area. The Project

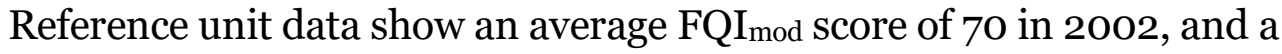
consistent FQImod decline to approximately 50 by 2015. The vegetation survey data in Figure 4 show that during this period, the PR stations transitioned to higher $\mathrm{CC}$ communities (common and dominant vegetation), so the declining FQI mod scores indicate a landscape that is transitioning from higher cover values to one of significantly less cover. The Project area wetlands were constructed in 2007, and by the first vegetation survey in 2008, the Project sites had a mean FQImod score of approximately 78. This score is near the ideal range for brackish marsh in Louisiana's inactive Deltaic Plain (Cretini et al. 2011), and higher than any mean FQImod observed in the PR or SR units. The Project exhibited declining mean FQImod scores from 2008 to 2012, reaching a minimum of approximately 64. These conditions were probably influenced by Hurricanes Gustav and Isaac in 2008 and 2012, respectively. The inset chart in Figure 8 also shows monthly average salinity from the Project CRMS station. There was one moderately high salinity spike that was observed across this period of record. The $11.1 \mathrm{ppt}$ spike occurred in 2011, and may have contributed to lowering FQImod values. From 2012 to 2015, the Project FQImod scores show moderately increasing trends, having intersected the SR trajectory in 2014, and reaching an FQImod score of approximately 70 in 2015. These increases in FQImod scores represent a Project landscape that is effectively recovering from stressors (i.e., hurricane impacts) and has higher recent wetland function than the PR and SR wetlands. 
Figure 8. Floristic Quality Index (FQImod) scores for all survey stations within the Little Lake assessment units by year. Vertical lines and inset chart provide tropical storm (TS) activity (wind speed miles per hour) and salinity data, respectively.

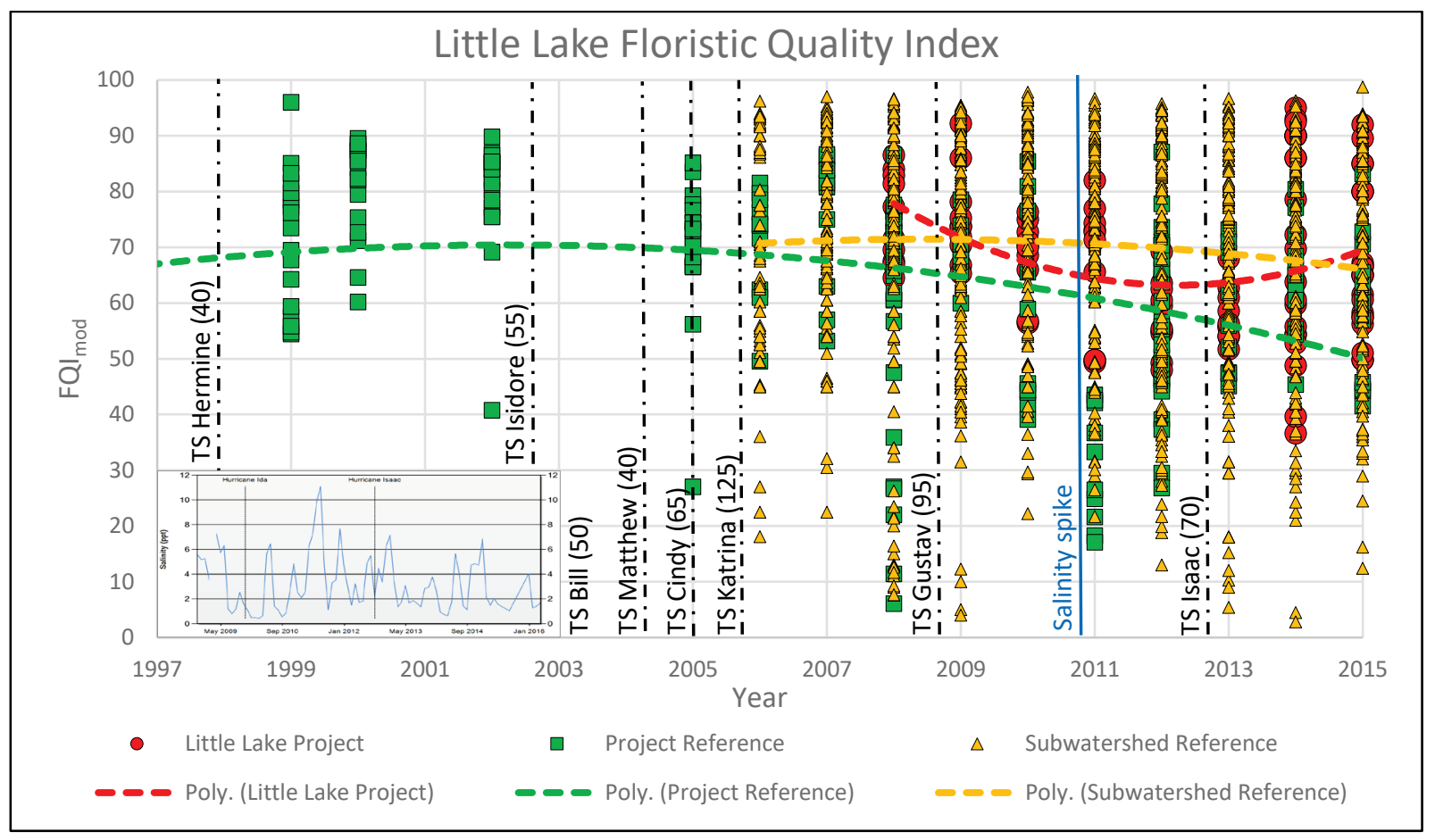

\subsubsection{FQI summary}

Table 4 provides FQImod summary information for all Sabine study site assessment units by year. The FQImod mean values are reported with a \pm 1 standard error (SE) of the mean. To compare FQI mod, the 95\% confidence interval of the sample means were estimated using two times the standard error ( $m \pm 2 \mathrm{SE}$ ) (Matthews 2016). Also provided are the differences in means between Project and PR and SR units. The difference values are color ramped, with green representing positive values (darker greens are higher values) and red representing negative values (darker reds are lower values). With regard to floristic quality, the overall Sabine averages show that the Project sites performed better than the PR and SR sites, 69.4 versus 65.0 and 37.0, respectively. The average difference in FQImod values between the Sabine Project and SR units for paired years was 44.1. The

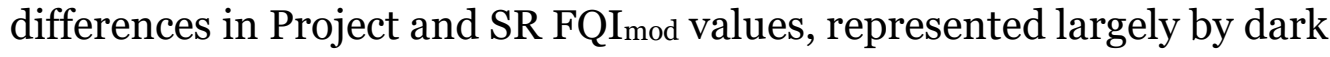
green colors, indicate landscapes at opposite ends of the wetland condition spectrum. The restored Project unit is experiencing robust vegetative growth, while the SR unit is continuing along a trend of wetland degradation. Excluding a few years (hurricane and salinity impacts), the average FQImod by year for the Project unit was above or near the preliminary ideal range reported by Cretini et al. (2011), where the average 
FQI mod within the SR unit experienced only one of fourteen years at or above the ideal range, with the majority of years significantly below the ideal range. The Project and PR units were more similar in overall mean FQI mod. Comparing the confidence intervals of the twelve paired Project and PR unit means, six were significantly different (five with higher Project values) and six were not significantly different. The years (2004, 2005, 2010, and 2011) where the PR means were higher (regardless of significance) were in periods where hurricane and salinity impacts affected Project FQImod values. It is theorized that the differences in these impacts were largely driven by landscape maturity and stability, and variations in hydrology (e.g., impoundments due to containment dikes). Generally, the Project unit outperformed the PR unit, and if hurricane-impacted years are excluded, the Project unit had an overall FQImod average that was ten points higher than the PR unit.

Table 4. Mean FQImod by year for each assessment unit within the Sabine study sites. Differences in FQI between Project (P) and Subwatershed Reference (SR) and Project Reference (PR) are provided and color coded (dark green represents difference values near 100 and dark red represents values near -100 ).

\begin{tabular}{|c|c|c|c|c|c|}
\hline \multirow{2}{*}{ Year } & \multicolumn{5}{|c|}{ Sabine (Average FQImod) } \\
\hline & SR & Difference between $P$ and SR & $\mathbf{P}$ & Difference between P and PR & PR \\
\hline 1997 & $80.2 \pm 2.1$ & & & & \\
\hline 1998 & & & & & \\
\hline 1999 & $55.4 \pm 6.9$ & & & & $75.9 \pm 2.1$ \\
\hline 2000 & & & & & \\
\hline 2001 & & & & & $79.9 \pm 3.0$ \\
\hline 2002 & & & & & $76.5 \pm 3.4$ \\
\hline 2003 & & & & & \\
\hline 2004 & $45.1 \pm 12.7$ & 14.8 & $59.9 \pm 9.3$ & -6.2 & $66.1 \pm 2.0$ \\
\hline 2005 & & & $1.4 \pm 0.6$ & -31.9 & $33.3 \pm 5.7$ \\
\hline 2006 & $0.7 \pm 0.7$ & 89.3 & $90.0 \pm 1.5$ & 44.6 & $45.4 \pm 6.4$ \\
\hline 2007 & $9.8 \pm 9.3$ & 72.1 & $81.9 \pm 1.7$ & 28.7 & $53.2 \pm 4.5$ \\
\hline 2008 & $17.5 \pm 13.2$ & 55.4 & $72.9 \pm 7.1$ & 5.0 & $67.9 \pm 5.0$ \\
\hline 2009 & $13.2 \pm 3.5$ & 56.9 & $70.1 \pm 0.0$ & 25.0 & $45.1 \pm 5.6$ \\
\hline 2010 & $44.2 \pm 9.8$ & 33.9 & $78.1 \pm 5.2$ & -3.7 & $81.8 \pm 1.8$ \\
\hline 2011 & $48.1 \pm 7.6$ & 14.3 & $62.4 \pm 0.0$ & -5.0 & $67.4 \pm 6.1$ \\
\hline 2012 & $34.9 \pm 21.0$ & 46.6 & $81.5 \pm 3.0$ & 14.3 & $67.2 \pm 4.1$ \\
\hline 2013 & $43.9 \pm 12.7$ & 32.0 & $75.9 \pm 0.0$ & 12.9 & $63.0 \pm 3.3$ \\
\hline 2014 & $40.3 \pm 9.1$ & 39.2 & $79.5 \pm 2.2$ & 0.9 & $78.6 \pm 2.2$ \\
\hline 2015 & $47.9 \pm 14.6$ & 31.1 & $79.0 \pm 1.9$ & 5.8 & $73.2 \pm 4.4$ \\
\hline Average & $37.0 \pm 6.0$ & 44.1 & $69.4 \pm 6.6$ & 7.5 & $65.0 \pm 3.8$ \\
\hline
\end{tabular}

The mean \pm the standard error is given for the FQImod variable.

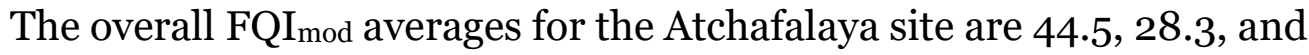
16.2, for the SR, Project, and PR units, respectively (Table 5). The yearly FQI mod averages for the SR unit ranged from 39.3 to 49.2. These FQImod values remained relatively steady over the 18 -year period of analysis, but were well below the ideal range $(>70)$ that was established by Cretini et al. (2011) for an active deltaic plain. However, Cretini et al. (2011) reported that their preliminary ranges may require future adjustments. Since the SR sites are in some of the most productive and vigorous wetlands in 
South Louisiana, it may be that a more appropriate ideal range has a minima FQI mod $_{\text {near }} 50$. The overall difference in average between

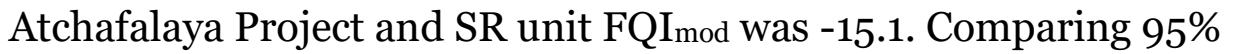
confidence intervals ( $m \pm 2 \mathrm{SE}$ ), the SR unit means were significantly higher than the Project FQI mod means in all four paired years. These differences were primarily due to the mature condition of the established mainland SR wetlands compared to the immature and early successional wetlands in the constructed Project unit. The PR unit is also immature and in early successional stages, but is pro-grading and accreting through natural processes via the Wax Lake Outlet. The 13.3 difference in overall average FQI mod between the Project and PR units may be related to the differences in natural and construction processes and subsequent differences in elevation. Comparing 95\% confidence intervals ( $m \pm 2 \mathrm{SE})$, the Project unit means were significantly higher than the PR FQImod means in most of the paired years (slight overlap in confidence intervals in 2014). Generally, the yearly FQI mod averages for all units remained relatively consistent (less than or equal to $\pm 8 \mathrm{FQI}$ mod of the overall average), except for 2013, where the landscape was still exhibiting impacts from Hurricane Isaac. The SR mainland unit outperformed the Project and PR units, but those differences are primarily related to elevation and wetland maturity.

The overall FQI mod averages for Little Lake were similar for all assessment units (Table 6). The Project unit had a slightly higher overall FQImod score (67.4) than the SR (66.9) or PR (64.5) units. With regard to yearly FQImod means, the Little Lake Project site had slightly higher scores than the SR site, though based on the $95 \%$ confidence intervals, only one out of eight paired years were significantly different. These scores, ranging from 57.8 to 75.3 for the Project unit, and 62.4 to 74.5 for the SR, are lower than the ideal range reported by Cretini et al. (2011), but are probably high for a rapidly subsiding landscape experiencing recent hurricane impacts and frequent fluctuations in salinity. Though the overall average FQI mod $_{\text {scores }}$ in Project and PR units were also similar, there was a wide range of withinyear differences. Seven of eight paired years show the mean FQImod values were higher in the Little Lake Project unit than in the PR, though based on the $95 \%$ confidence intervals, only one year was significantly higher. The differences ranged from a low of -0.7 in 2013 to a high of 35.8 in 2011. The larger differences in paired FQI $I_{\text {mod }}$ values between Project and PR units were observed in 2008 and 2011. These differences are probably related to Hurricane Gustav's impact to the region in 2008 and the higher salinity event that occurred in 2011 (possible effects of Tropical Storm Arlene), and the protection that containment dikes provided to the Project unit. 
Table 5. Mean FQImod by year for each assessment unit within the Atchafalaya study sites.

Differences in FQI between Project (P) and Subwatershed Reference (SR) and Project Reference (PR) are provided and color coded (dark green represents difference values near 100 and dark red represents values near -100).

\begin{tabular}{|c|c|c|c|c|c|}
\hline \multirow{2}{*}{ Year } & \multicolumn{5}{|c|}{ Atchafalaya (Average FQI ${ }_{\text {mod }}$ ) } \\
\hline & SR & Difference between $\mathrm{P}$ and $\mathrm{SR}$ & $\mathbf{P}$ & Difference between $P$ and $P R$ & PR \\
\hline 1997 & $40.2+8.5$ & & & & \\
\hline 1998 & & & & & \\
\hline 1999 & & & $30.3 \pm 4.0$ & & \\
\hline 2000 & & & & & \\
\hline 2001 & & & & & \\
\hline 2002 & & & $21.6 \pm 4.1$ & & \\
\hline 2003 & & & & & \\
\hline 2004 & & & & & \\
\hline 2005 & & & & & \\
\hline 2006 & $39.3 \pm 6.4$ & & & & \\
\hline 2007 & $45.3 \pm 2.4$ & -20.1 & $25.2 \pm 2.4$ & 11.1 & $14.1 \pm 3.3$ \\
\hline 2008 & $42.9 \pm 2.6$ & & & & $23.1 \pm 3.7$ \\
\hline 2009 & $49.2 \pm 2.5$ & & & & $18.1 \pm 5.1$ \\
\hline 2010 & $47.8 \pm 2.6$ & & & & $16.4 \pm 3.1$ \\
\hline 2011 & $48.4 \pm 2.9$ & & & & $24.5 \pm 1.9$ \\
\hline 2012 & $40.5 \pm 2.1$ & & & & $11.5 \pm 2.6$ \\
\hline 2013 & $45.9 \pm 2.7$ & & & & $2.4 \pm 0.5$ \\
\hline 2014 & $43.9 \pm 2.1$ & -12.8 & $31.1 \pm 1.8$ & 8.8 & $22.3 \pm 3.3$ \\
\hline 2015 & $45.6 \pm 2.6$ & -12.3 & $33.3 \pm 2.8$ & 20.1 & $13.2 \pm 2.1$ \\
\hline Average & $44.5 \pm 1.0$ & -15.1 & $28.3 \pm 2.1$ & 13.3 & $16.2 \pm 2.3$ \\
\hline
\end{tabular}

The mean \pm the standard error is given for the $F \mathrm{II}_{\bmod }$ variable.

Table 6. Mean FQImod by year for each assessment unit within the Little Lake study sites. Differences in FQI between Project (P) and Subwatershed Reference (SR) and Project Reference (PR) are provided and color coded (dark green represents difference values near 100 and dark red represents values near -100).

\begin{tabular}{|c|c|c|c|c|c|}
\hline \multirow{2}{*}{ Year } & \multicolumn{5}{|c|}{ Little Lake (Average FQI ${ }_{\text {mod }}$ ) } \\
\hline & SR & Difference between $\mathbf{P}$ and & $\mathbf{P}$ & Difference between P and PR & PR \\
\hline \multicolumn{6}{|l|}{1997} \\
\hline \multicolumn{6}{|l|}{1998} \\
\hline 1999 & & & & & $71.4 \pm 3.0$ \\
\hline 2000 & & & & & $80.7 \pm 2.2$ \\
\hline \multicolumn{6}{|l|}{2001} \\
\hline 2002 & & & & & $79.2 \pm 2.7$ \\
\hline \multicolumn{6}{|l|}{2003} \\
\hline \multicolumn{6}{|l|}{2004} \\
\hline 2005 & & & & & $70.0 \pm 3.2$ \\
\hline 2006 & $66.9 \pm 1.9$ & & & & $70.9 \pm 3.2$ \\
\hline 2007 & $74.5 \pm 1.6$ & & & & $75.1 \pm 4.0$ \\
\hline 2008 & $68.7 \pm 2.1$ & 6.5 & $75.2 \pm 2.6$ & 16.6 & $58.6 \pm 4.3$ \\
\hline 2009 & $68.2 \pm 1.5$ & 7.2 & $75.3 \pm 2.6$ & 5.4 & $70.0 \pm 1.6$ \\
\hline 2010 & $64.9 \pm 2.1$ & 3.4 & $68.3 \pm 2.2$ & 10.1 & $58.2 \pm 5.6$ \\
\hline 2011 & $65.2 \pm 1.8$ & 1.3 & $66.5 \pm 3.9$ & 35.8 & $30.7 \pm 3.3$ \\
\hline 2012 & $64.3 \pm 1.7$ & -6.6 & $57.8 \pm 2.1$ & 1.4 & $56.4 \pm 2.8$ \\
\hline 2013 & $66.6 \pm 1.9$ & -8.8 & $57.8 \pm 1.5$ & -0.7 & $58.5 \pm 3.3$ \\
\hline 2014 & $62.4 \pm 1.9$ & 8.5 & $70.9 \pm 4.0$ & 6.7 & $64.2 \pm 2.6$ \\
\hline 2015 & $67.2 \pm 1.7$ & 0.5 & $67.7 \pm 2.8$ & 8.6 & $59.1 \pm 3.8$ \\
\hline Average & $66.9 \pm 1.0$ & 1.5 & $67.4 \pm 2.4$ & 10.5 & $64.5 \pm 3.4$ \\
\hline
\end{tabular}

The mean \pm the standard error is given for the FQImod variable. 


\section{Conclusion}

Vegetation provides one of the best indicators for assessing the condition and performance of wetlands (Fennessy et al. 2002). However, using standard approaches with vegetation classification and cover data to assess wetland condition and restoration performance can be demanding, especially with long periods of analyses and large quantities of data. Though these standard measures provide assessments of vegetation species presence and abundance (percentage of cover), using these measures to compare the condition of one wetland area to another would benefit from complementary methods more aligned to assess quality. Therefore, the purpose of this study was to evaluate the utility of an FQI mod for assessing the performance and resilience of restored wetlands by comparing those to reference wetlands.

Though the standard FQI approach was originally established to assess disturbance impacts on naturally occurring vegetation communities, it is theoretically suited for assessing the establishment and development of created wetlands and comparing those to wetlands at varying scales and chronosequence. The results of this study show that the FQImod data successfully reflected large disturbance events, namely hurricanes and major fluxes in salinity. The FQImod assessments also successfully identified differences due to wetland elevation, age, and hydrology. The modified FQI also provides measures of restoration type (e.g., planted versus not planted, marsh creation versus nourishment), chronosequence (condition and stability over time), and trajectory (i.e., intersecting trend lines when restored marsh FQI approaches reference marsh condition).

Though the FQImod provides a useful complementary monitoring tool to use with standard vegetation assessments, there remain limitations and knowledge gaps. FQImod data are discretely sampled data that require time and labor-intensive field work. Additionally, $\mathrm{CC}$ values have not been developed for all states or regions within the United States. FQI mod alone will not describe every aspect of wetland condition, so it must be complemented by indices describing hydrologic and other functional processes to develop a more complete assessment of wetland condition. Future work should include methods that provide continuous spatial data (vegetation quality and productivity), which would allow for more representative FQI mod assessments over larger landscape areas. These modifications could be incorporated into higher level assessment systems 
(i.e., Level 3 - intensive site assessments) if more comprehensive evaluations of wetland form and function are required (DeKeyser et al. 2003).

Overall, FQImod provides a rapid and effective system for spatially and temporally assessing wetland condition and performance. Combining an FQI mod with additional measures of wetland function (e.g., hydrology, soils, and elevation) can ultimately assist in future wetland restoration planning and adaptive management. 


\section{References}

Andreas, B. K., J. J. Mack, and J. S. McCormac. 2004. Floristic Quality Assessment Index (FQAI) for vascular plants and mosses for the State of Ohio. Ohio Environmental Protection Agency, Division of Surface Water, Wetland Ecology Group, Columbus, Ohio.

Barras, J. A. 2005. Land area changes in coastal Louisiana after Hurricanes Katrina and Rita. Science and the storms: the USGS response to the hurricanes of 2005.

Bourdaghs, M., C. A. Johnston, and R. R. Regal. 2006. Properties and Performance of the Floristic Quality Index in Great Lakes Coastal Wetlands. Wetlands 26(3): 718735 .

Brown, Cunningham, \& Gannuch Inc. 1998. Engineering Closure Report Big Island Mining (XAT-7) and Atchafalaya Sediment Delivery (PAT-2) As-Built Construction Phase. Prepared for State of Louisiana Department of Natural Resources and National Marine Fisheries Service DNR Contract No. 25085-9504 .

Carle, M. V. 2013. Spatial structure and dynamics of the plant communities in a prograding river delta: Wax Lake Delta, Atchafalaya Bay, Louisiana. PhD diss., LSU.

Carle, M. V., C. E. Sasser, and H. H. Roberts. 2013. Accretion and vegetation community change in the Wax Lake Delta following the historic 2011 Mississippi River flood. Journal of Coastal Research 313:569-587.

Chamberlain, S. J. and H. M. Ingram. 2012. Developing coefficients of conservatism to advance floristic quality assessment in the Mid-Atlantic region. Journal of the Torrey Botanical Society 139(4): 416-427.

Coastal Protection and Restoration Authority (CPRA) of Louisiana. 2012. Louisiana's Comprehensive Master Plan for a Sustainable Coast. Coastal Protection and Restoration Authority of Louisiana. Baton Rouge, LA.

Coastal Protection and Restoration Authority (CPRA) of Louisiana. 2016. Coastwide Reference Monitoring System-Wetlands Monitoring Data. Retrieved from Coastal Information Management System (CIMS) database.

http://cims.coastal.louisiana.gov. Accessed 27 February 2016.

Coastal Wetlands Planning, Protection, and Restoration Act (CWPPRA). 2016. The Atchafalaya Basin. https://lacoast.gov/new/About/Basin data/at/Default.aspx. Accessed May 27, 2016.

Cohen, M. J., S. Carstenn, and C. R. Lane. 2004. Floristic Quality Indices for Biotic Assessment of Depressional Marsh Condition in Florida. Ecol. Appl., 14(3): 784794 .

Couvillion, B. R., J. A. Barras, G. D. Steyer, W. Sleavin, M. Fischer, H. Beck, N. Trahan, B. Griffin, and D. Heckman. 2011. Land area change in coastal Louisiana from 1932 to 2010: U.S. Geological Survey Scientific Investigations Map 3164, scale 1:265,000, 12 p. pamphlet. 
Cretini, K. F., J. M. Visser, K. W. Krauss, and G. D. Steyer. 2011. CRMS vegetation analytical team framework-Methods for collection, development, and use of vegetation response variables: U.S. Geological Survey Open-File Report 20111097.

Cretini, K. F., J. M. Visser, K. W. Krauss, and G. D. Steyer. 2012. Development and use of a floristic quality index for coastal Louisiana marshes. Environmental monitoring and assessment 184(4): 2389-2403.

Curole, G. P. 2003. Monitoring Plan for Big Island Mining (AT-03), Coastal Protection and Restoration Authority of Louisiana, Office of Coastal Protection and Restoration, Lafayette, Louisiana.

Curole, G. P. and B. J. Babin. 2010. 2010 Operations, Maintenance, and Monitoring Report for Big Island Mining (AT-03), Coastal Protection and Restoration Authority of Louisiana, Office of Coastal Protection and Restoration, Thibodaux, Louisiana.

Dahl, T. E. 2010. Status and Trends of Wetlands in the Conterminous United States 2004 to 2009. Washington, DC: U.S. Fish and Wildlife Service.

Dahl, T. E. and G. J. Allord. 1996. Technical Aspects of Wetlands History of Wetlands in the Conterminous United States. National Water Summary on Wetlands Resources. United States Geological Survey Water Supply Paper 2425.

DeKeyser, E. S., D. R. Kirby, and M. J. Ell. 2003. An index of plant community integrity: development of the methodology for assessing prairie wetland plant communities. Ecological Indicators 3(2): 119-133.

Ervin, G. N., B. D. Herman, J. T. Bried, and D. C. Holly. 2006. Evaluating Non-Native Species and Wetland Indicator Status as Components of Wetlands Floristic Assessment. Wetlands 26(4): 1114-1129.

Fennessy, S., M. Gernes, J. Mack, and D. H. Wardrop. 2002. Methods for Evaluating Wetland Condition: Using Vegetation to Assess Environmental Conditions in Wetlands. U.S. Environmental Protection Agency, Office of Water, Washington, DC, USA. EPA 822-R-01-007j.

Folse, T. M., L. A. Sharp, J. L. West, M. K. Hymel, J. P. Troutman, T. E. McGinnis, D. Weifenbach, W. M. Boshart, L. B. Rodrigue, D. C. Richardi, W. B. Wood, and C. M. Miller. 2014. A Standard Operating Procedures Manual for the Coastwide Reference Monitoring System-Wetlands: Methods for Site Establishment, Data Collection, and Quality Assurance/Quality Control. Baton Rouge, LA: Louisiana Coastal Protection and Restoration Authority.

Gianopulos, K. 2014. Coefficient of Conservatism Database Development for Wetland Plants Occurring in the Southeast United States. North Carolina Dept. of Environment \& Natural Resources, Division of Water Resources: Wetlands Branch. Report to the EPA, Region 4. 
GOTECH Inc. 2003. Environmental Assessment of Little Lake Shoreline Protection/Dedicated Dredging Near Round Lake CWPPRA Project BA-37. Prepared for the United States Department of Commerce National Oceanic and Atmosphere Administration National Marine Fisheries Service, Silver Spring, MD.

Herman, B. D., J. D. Madsen, and G. N. Ervin. 2006. Development of coefficients of conservatism for wetland vascular flora of north and central Mississippi. Geo Resources Institute Report, 4001.

Johnson, W. B., C. E. Sasser, and J. G. Gosselink. 1985. Succession of vegetation in an evolving river delta, Atchafalaya Bay, Louisiana. Journal of Ecology 73: 973-986.

Karr, J. R., and E. W. Chu. 1997. Biological monitoring and assessment: Using multimetric indexes effectively. EPA/235/R97/001. Seattle, Washington: University of Washington.

Lester, G. D., S. G. Sorensen, P. L. Faulkner, C. S. Reid, and I. E. Maxit. 2005. Louisiana Comprehensive Wildlife Conservation Strategy. Louisiana Department of Wildlife and Fisheries. Baton Rouge.

Little, A. 2013. Sampling and Analyzing Wetland Vegetation. In Wetland Techniques, 273-324. Springer Netherlands.

Louisiana Coastal Wetlands Conservation and Restoration Task Force (LCWCRTF). 2002. Big Island Mining (AT-03).

Louisiana Coastal Wetlands Conservation and Restoration Task Force (LCWCRTF). 2015a. The 2015 Evaluation Report to the U.S. Congress on the Effectiveness of Coastal Wetlands Planning, Protection and Restoration Act Projects.

Louisiana Coastal Wetlands Conservation and Restoration Task Force (LCWCRTF). 2015b. Little Lake Shoreline Protection/Dedicated Dredging Near Round Lake (BA-37).

Louisiana Office of Coastal Protection and Restoration. 2009. Operation, Maintenance, and Rehabilitation Plan Little Lake Shoreline Protection / Dedicated Dredging Project BA-37. Coastal Protection and Restoration Authority of Louisiana, Office of Coastal Protection and Restoration, Lafayette, Louisiana. 194pp.

Mack, J. J. 2007. Developing a wetland IBI with statewide application after multiple testing iterations. Ecological Indicators 7: 864-881.

Matthews, J. N. S. 2016. Standard Errors and Confidence Intervals. School of Mathematics and Statistics, University of Newcastle. http://www.mas.ncl.ac.uk/ njnsm/medfac/docs/se\&ci.pdf. Accessed May $16,2016$.

Matthews, J. W., G. Spyreas, and A. G. Endress. 2009. Trajectories of vegetation-based indicators used to assess wetland restoration progress. Ecological Applications 19(8): 2093-2107.

Millennium Ecosystem Assessment. 2003. Ecosystems and human well-being. Washington, DC: Island Press, Vol. 200. 
Miller, M. 2014. 2014 Operations, Maintenance, and Monitoring Report for Sabine Refuge Marsh Creation (CS-28). Coastal Protection and Restoration Authority of Louisiana, Coastal Protection and Restoration, Lafayette, Louisiana. 25pp.

Mushet, D. M., N. H. Euliss, and T. L. Shaffer. 2002. Floristic quality assessment of one natural and three restored wetland complexes in North Dakota, USA. Wetlands 22(1): 126-138.

Mortellaro, S., M. Barry, G. Gann, J. Zahina, S. Channon, C. Hilsenbeck, D. Scofield, G. Wilder, and G. Wilhelm. 2012. Coefficients of conservatism values and the floristic quality index for the vascular plants of South Florida. Southeastern Naturalist 11(3): 1-62.

National Marine Fisheries Service (NMFS). 2001. Little Lake Shoreline Protection/Dedicated Dredging near Round Lake Wetland Value Assessment. National Oceanic and Atmospheric Administration National Marine Fisheries Service, Baton Rouge, Louisiana.

Nichols, S. A. 1999. Floristic Quality Assessment of Wisconsin Lake Plant Communities with Example Applications. Lake and Reservoir Management 15(2): 133-141.

Rocchio, J. 2007. Floristic Quality Assessment Indices for Colorado plant communities. Colorado Natural Heritage Program: Colorado State University..

Sasser, C., J. Visser, E. Mouton, J. Linscombe, and S. Hartley. 2014. Vegetation types in coastal Louisiana in 2013. US Geological Survey Scientific Investigations Map, $3290(1)$.

Sharp, L. A. 2003. Monitoring Plan for Sabine Refuge Marsh Creation (CS-28). Lafayette, Louisiana: Coastal Protection and Restoration Authority of Louisiana, Office of Coastal Protection and Restoration.

Smith, R. D., A. Ammann, C. Bartoldus, and M. M. Brinson. 1995. An approach for assessing wetland function using hydrogeomorphic classification, reference wetlands, and functional indices.Technical Report WRP-DE-9. Vicksburg, MS: Waterways Experiment Station.

Stapanian, M. A., W. Schumacher, G. Gara, and S. E. Monteith. 2016. Negative effects of excessive soil phosphorus on floristic quality in Ohio wetlands. Science of the Total Environment 551: (556-562).

Steyer, G. D., and R. E. Stewart, Jr. 1992. Monitoring Program for Coastal Wetlands Planning, Protection, and Restoration Act Projects. U.S. Fish and Wildlife Service, National Wetlands Research Center Open File Report 9341.

Swink, F. and G. S. Wilhelm. 1979. Plants of the Chicago Region, revised and expanded edition with keys. Lisle, IL: The Morton Arboretum.

Swink, F. and G. S. Wilhelm. 1994. Coefficients of Conservatism and Floristic Quality Assessment. Plants of the Chicago Region.

U.S. Army Corps of Engineers (USACE). 2013. St. Johns Bayou New Madrid Floodway Project. Draft Environmental Impact Statement. U.S. Army Corps of Engineers, Memphis District. 
U.S. Environmental Protection Agency (USEPA). 2002a. Methods for Evaluating Wetland Condition: Using Vegetation to Assess Environmental Conditions in Wetlands. EPA-822-R-02-020. Washington, DC: U.S. Environmental Protection Agency, Office of Water.

U.S. Environmental Protection Agency (USEPA). 2002b. Wetland monitoring and assessment: A technical framework. EPA 843-F-02-002(h). Washington, DC: US Environmental Protection Agency.

Votteler, T. H. and T. A. Muir. 1996. Wetland Management and Research Wetland Protection Legislation. National Water Summary on Wetlands Resources. United States Geological Survey Water Supply Paper 2425. 


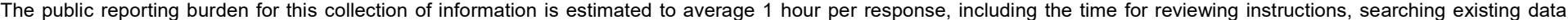

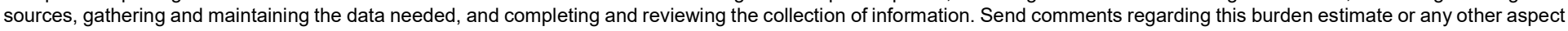

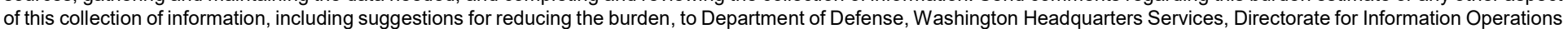

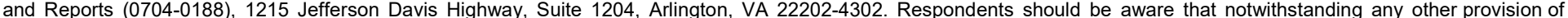
law, no person shall be subject to any penalty for failing to comply with a collection of information if it does not display a currently valid OMB control number.

PLEASE DO NOT RETURN YOUR FORM TO THE ABOVE ADDRESS.

\begin{tabular}{l|l|l}
\hline 1. REPORT DATE & 2. REPORT TYPE & 3. DATES COVERED (From - To) \\
August 2017 & Final & Oct $2014-$ June 2017
\end{tabular}

Oct 2014 - June 2017

\section{TITLE AND SUBTITLE}

Floristic Quality Index of Restored Wetlands in Coastal Louisiana

5a. CONTRACT NUMBER

5b. GRANT NUMBER

N/A

5c. PROGRAM ELEMENT NUMBER

$\mathrm{N} / \mathrm{A}$

6. AUTHOR(S)

Glenn M. Suir and Charles E. Sasser

\section{PERFORMING ORGANIZATION NAME(S) AND ADDRESS(ES)}

Environmental Laboratory U.S. Army Engineer Research and Development Center 3909 Halls Ferry Road Vicksburg, MS 39180-6199

\section{SPONSORING/MONITORING AGENCY NAME(S) AND ADDRESS(ES)}

Headquarters, U.S. Army Corps of Engineers

Washington, DC 20314-1000

12. DISTRIBUTION/AVAILABILITY STATEMENT

Approved for public release; distribution is unlimited.

\section{SUPPLEMENTARY NOTES N/A}

\section{ABSTRACT}

Restoration efforts in the United States have created or benefitted large expanses of wetlands. Typical goals of wetland restoration efforts are to conserve, create, or enhance wetland form and to achieve wetland function that approaches natural conditions. Measures of wetland condition have been used to monitor and assess project performance, resilience, and adaptive management needs. An emerging tool for performing bioassessments in wetland systems is the Floristic Quality Index (FQI). This study assessed the use of a modified FQI (FQI $\mathrm{Imd}_{\mathrm{mo}}$ to evaluate site development, plant community establishment, and wetland condition. Three restoration sites in coastal Louisiana were used to evaluate the utility of an $\mathrm{FQI}_{\mathrm{mod}}$ for assessing the performance and resilience of restored wetlands by comparison to reference wetlands. Results demonstrate that the $\mathrm{FQI}_{\text {mod }}$ data successfully reflected large disturbance events — namely hurricanes and salinity spikes. The data also identified vegetation differences due to elevation, age, and hydrology. The modified FQI provided useful measures of restoration type (e.g., planted versus not planted, marsh creation versus nourishment), chronosequence (condition and stability over time), and trajectory (i.e., intersecting trend lines when restored marsh FQI approaches reference marsh condition). The FQI ${ }_{\text {mod }}$ provides a rapid and effective system for assessing wetland condition and performance.

\begin{tabular}{|c|c|c|c|c|c|}
\hline \multicolumn{3}{|c|}{$\begin{array}{l}\text { 15. SUBJECT TERMS } \\
\text { Ecosystem Resilience } \\
\text { Wetland Condition } \\
\text { Wetlands - Louisiana }\end{array}$} & \multicolumn{2}{|c|}{$\begin{array}{l}\text { Floristic Quality } \\
\text { Adaptive Management } \\
\text { Coefficient of Conservatism } \\
\text { Environmental management }\end{array}$} & $\begin{array}{l}\text { Wetland Restoration } \\
\text { Bioassessments } \\
\text { Restoration ecology }\end{array}$ \\
\hline \multicolumn{3}{|c|}{ 16. SECURITY CLASSIFICATION OF: } & \multirow{3}{*}{$\begin{array}{l}\text { 17. LIMITATION OF } \\
\text { ABSTRACT } \\
\text { SAR }\end{array}$} & \multirow{3}{*}{$\begin{array}{l}\text { 18. NUMBER OF } \\
\text { PAGES } \\
44\end{array}$} & \multirow{2}{*}{$\begin{array}{l}\text { 19a. NAME OF RESPONSIBLE PERSON } \\
\text { Glenn M. Suir }\end{array}$} \\
\hline \multirow{2}{*}{$\begin{array}{l}\text { a. REPORT } \\
\text { Jnlimited }\end{array}$} & \multirow{2}{*}{$\begin{array}{l}\text { b. ABSTRACT } \\
\text { Unlimited }\end{array}$} & \multirow{2}{*}{$\begin{array}{l}\text { c. THIS PAGE } \\
\text { Unlimited }\end{array}$} & & & \\
\hline & & & & & $\begin{array}{l}\text { 19b. TELEPHONE NUMBER (Include area code) } \\
\text { 225-578-7417 }\end{array}$ \\
\hline
\end{tabular}

Standard Form 298 (Rev. 8/98)

Prescribed by ANSI Std. Z39.18 